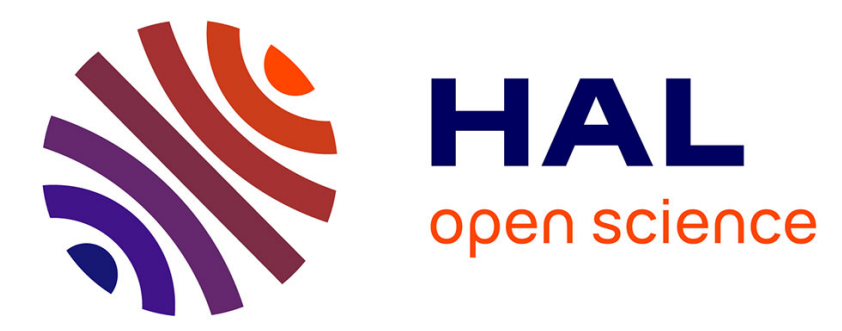

\title{
Tubelike Uranyl-Phenylenediacetate Assemblies from Screening of Ligand Isomers and Structure-Directing Counterions
}

Pierre Thuéry, Youssef Atoini, Jack Harrowfield

\section{- To cite this version:}

Pierre Thuéry, Youssef Atoini, Jack Harrowfield. Tubelike Uranyl-Phenylenediacetate Assemblies from Screening of Ligand Isomers and Structure-Directing Counterions. Inorganic Chemistry, 2019, 58, pp.6550-6564. 10.1021/acs.inorgchem.9b00804 . cea-02113631

HAL Id: cea-02113631

https://hal-cea.archives-ouvertes.fr/cea-02113631

Submitted on 29 Apr 2019

HAL is a multi-disciplinary open access archive for the deposit and dissemination of scientific research documents, whether they are published or not. The documents may come from teaching and research institutions in France or abroad, or from public or private research centers.
L'archive ouverte pluridisciplinaire HAL, est destinée au dépôt et à la diffusion de documents scientifiques de niveau recherche, publiés ou non, émanant des établissements d'enseignement et de recherche français ou étrangers, des laboratoires publics ou privés. 


\title{
Tubelike Uranyl-Phenylenediacetate Assemblies from Screening of Ligand Isomers and Structure-Directing Counterions
}

\author{
Pierre Thuéry, ${ }^{* \dagger} \dagger$ Youssef Atoini ${ }^{\ddagger}$ and Jack Harrowfield $* *$ \\ ${ }^{\dagger}$ NIMBE, CEA, CNRS, Université Paris-Saclay, CEA Saclay, 91191 Gif-sur-Yvette, France \\ ${ }^{\ddagger}$ ISIS, Université de Strasbourg, 8 allée Gaspard Monge, 67083 Strasbourg, France
}

\begin{abstract}
Reaction of 1,2- 1,3-, or 1,4-phenylenediacetic acids (1,2- 1,3-, or 1,4- $\left.\mathrm{H}_{2} \mathrm{PDA}\right)$ with uranyl ions under solvo-hydrothermal conditions and in the presence of $\left[\mathrm{M}(\mathrm{L})_{n}\right]^{q+}$ cations, in which $\mathrm{M}=$ transition metal cation, $\mathrm{L}=2,2^{\prime}$-bipyridine (bipy) or 1,10-phenanthroline (phen), $n=2$ or 3 , and $q=1$ or 2 , gave ten complexes which have been crystallographically characterized. The diacetate ligands are bis-chelating and the uranyl cations are tris-chelated in all cases. $\left[\mathrm{UO}_{2}(1,2-\mathrm{PDA})_{2} \mathrm{Zn}(\mathrm{phen})_{2}\right] \cdot 2 \mathrm{H}_{2} \mathrm{O}(\mathbf{1})$ and $\left[\mathrm{UO}_{2}(1,4-\mathrm{PDA})_{2} \mathrm{Mn}(\text { bipy })_{2}\right] \cdot \mathrm{H}_{2} \mathrm{O}(\mathbf{2})$ are heterometallic, neutral one-dimensional (1D) coordination polymers in which the carboxylate-coordinated $3 \mathrm{~d}$ block metal cation is either decorating only (1), or participates in polymer building (2). [ $\left.\mathrm{Zn}(\mathrm{phen})_{3}\right]\left[\left(\mathrm{UO}_{2}\right)_{2}(1,3-\right.$ $\left.\mathrm{PDA})_{3}\right](3)$ and $\left[\mathrm{Ni}(\text { phen })_{3}\right]\left[\left(\mathrm{UO}_{2}\right)_{2}(1,4-\mathrm{PDA})_{3}\right] \cdot \mathrm{H}_{2} \mathrm{O}(\mathbf{4})$, with separate counterions, crystallize as anionic twodimensional (2D) networks, as does $\left[\mathrm{Cu}(\text { bipy })_{2}\right]\left[\mathrm{H}_{2} \mathrm{NMe}_{2}\right]\left[\left(\mathrm{UO}_{2}\right)_{2}(1,4-\mathrm{PDA})_{3}\right](\mathbf{5})$, which displays parallel 2D interpenetration. The complex $\left[\mathrm{Zn}(\mathrm{phen})_{3}\right]\left[\left(\mathrm{UO}_{2}\right)_{2}(1,2-\mathrm{PDA})_{3}\right] \cdot 7 \mathrm{H}_{2} \mathrm{O}$ (6) crystallizes as a ladderlike, slightly inflated ribbon. The same topology is found in $\left[\mathrm{Zn}(\text { bipy })_{3}\right]\left[\left(\mathrm{UO}_{2}\right)_{2}(1,3-\mathrm{PDA})_{3}\right](7)$, but the larger separation between coordination sites and the coexistence of curved and divergent ligand conformations produce a tubelike assembly. An analogous, but more regular and spacious tubular geometry is found in $\left[\mathrm{M}(\mathrm{bipy})_{3}\right]\left[\left(\mathrm{UO}_{2}\right)_{2}(1,4-\right.$ PDA $\left.)_{3}\right]$ with $\mathrm{M}=\mathrm{Co}(\mathbf{8})$ or $\mathrm{Ni}(\mathbf{9})$, and $\left\{\Lambda-\left[\mathrm{Ru}(\text { bipy })_{3}\right]\right\}\left[\left(\mathrm{UO}_{2}\right)_{2}(1,4-\mathrm{PDA})_{3}\right](\mathbf{1 0})$. The disordered counterions in 8 and $\mathbf{9}$ are replaced by well-ordered, enantiomerically pure chiral counterions in 10. The tubular assemblies formed in 7-10 are characterized by an oblong section and the presence of gaps in the walls, which enable the inclusion of two rows of counterions in the cavity.
\end{abstract}




\section{INTRODUCTION}

In recent years, the investigation of the polynuclear or polymeric assemblies formed by the uranyl cation with organic ligands, in particular polycarboxylates, has become one of the most prolific areas in actinide chemistry. ${ }^{1-5}$ Among the huge diversity of architectures generated in these systems, closed species displaying well-defined cavities are steadily growing in importance, although they still constitute but a small subset. ${ }^{5,6}$ The first examples of uranylbased nanotubular assemblies, which can be considered as closed species of infinite length, incorporated phosphonate ligands, ${ }^{7-10}$ and several later examples were of purely inorganic nature. ${ }^{1-13}$ Polycarboxylate ligands such as phthalate, ${ }^{14}$ iminodiacetate, ${ }^{15,16}$ Kemp's tricarboxylate, ${ }^{17}$ cis,cis-1,3,5-cyclohexanetricarboxylate, ${ }^{18}$ and tricarballylate ${ }^{19}$ have been shown as well to give nanotubular uranyl complexes. In such cases, not only has the geometry of the ligand to be adapted to the formation of tubular polymers, but the proper templating species and synthetic conditions have to be found, which leaves much room for sheer luck. A case in point is that of tricarballylate which, depending on the counterions used, crystallizes as two-dimensional (2D) triangular or square-grooved nets or as square-section nanotubules. ${ }^{19}$

We have recently become engaged in an investigation of the effects of counterions of varying shape, bulkiness and modes of interaction on the dimensionality and topology of uranyl-organic assemblies. ${ }^{20-33}\left[\mathrm{M}(\mathrm{L})_{n}\right]^{q+}$ cations, in which $\mathrm{M}=$ transition metal cation, $\mathrm{L}=$ 2,2'-bipyridine (bipy) or 1,10-phenanthroline (phen), $n=2$ or 3, and $q=1$ or 2, appeared to be among the most productive $\mathrm{e}^{20-26}$ (it is notable that, even in the absence of carboxylate ligands, the $\mathrm{U} / \mathrm{M} / \mathrm{L}$ system has proven to be a rich area for investigation ${ }^{34}$ ). Systematic attempts at counterion modifications have been performed with several polycarboxylate ligands, such as aliphatic $\quad \alpha, \omega$-dicarboxylates, $\quad 4,4^{\prime}$-biphenyldicarboxylate, $\quad 1,2-, \quad 1,3-\quad$ and $\quad 1,4-$ cyclohexanedicarboxylates, 1,3-adamantanediacetate, or $(1 R, 3 S)-(+)$-camphorate, and they 
have given a wealth of complexes of varying geometries. In particular, several polynuclear cages have been obtained with ligands able to provide convergent ligating sites, ${ }^{21,30,31,33}$ as well as complexes displaying network entanglement, generally with ligands possessing divergent coordination sites. ${ }^{20,22-24,26,32}$

We have now examined a family of dicarboxylic acids comprised of three positional isomers, 1,2-1,3-, and 1,4-phenylenediacetic acids, with a geometry and flexibility suitable for the possible formation of closed species, while retaining also the possibility to act as divergent linkers, and we have used all three isomers to synthesize uranyl ion complexes incorporating different counterions. These ligands, for which no uranyl complex has been reported previous to this work, differ by their larger separation between ligating sites and their increased flexibility from the more commonly used 1,2-, 1,3-, and 1,4-benzenedicarboxylates, for which 17, 15 and 30 crystal structures of uranyl complexes, respectively, are reported in the Cambridge Structural Database (CSD, Version 5.39). ${ }^{35}$ While both the benzenedicarboxylates and the phenylenediacetates are formally considered as achiral molecules, they can in fact adopt chiral conformations which may be fixed in the solid state and this has been found to be a significant aspect of the coordination chemistry of the phenylenediacetates. In the formation of the complexes presently described, $\left[\mathrm{M}(\mathrm{L})_{n}\right]^{q+}$ cations have again proven to be efficient structure-directing agents, yielding ten complexes which have been characterized by their crystal structure and emission spectrum in the solid state, and including several which crystallize as nanotubular species as well as one forming a 2D interpenetrated assembly.

\section{EXPERIMENTAL SECTION}

Syntheses. Caution! Uranium is a radioactive and chemically toxic element, and uranium-containing samples must be handled with suitable care and protection. 
$\mathrm{UO}_{2}\left(\mathrm{NO}_{3}\right)_{2} \cdot 6 \mathrm{H}_{2} \mathrm{O}$ (depleted uranium, R. P. Normapur, 99\%), $\mathrm{Co}\left(\mathrm{NO}_{3}\right)_{2} \cdot 6 \mathrm{H}_{2} \mathrm{O}$, and $\mathrm{Ni}\left(\mathrm{NO}_{3}\right)_{2} \cdot 6 \mathrm{H}_{2} \mathrm{O}$ were purchased from Prolabo. $\mathrm{Cu}\left(\mathrm{NO}_{3}\right)_{2} \cdot 2.5 \mathrm{H}_{2} \mathrm{O}, \mathrm{Zn}\left(\mathrm{NO}_{3}\right)_{2} \cdot 6 \mathrm{H}_{2} \mathrm{O}, 1,2-, 1,3-$ and 1,4-phenylenediacetic acids, and 1,10-phenanthroline were from Aldrich, while $\mathrm{Mn}\left(\mathrm{NO}_{3}\right)_{2} \cdot 6 \mathrm{H}_{2} \mathrm{O}$ was from Alfa-Aesar, and 2,2'-bipyridine was from Fluka. Racemic $\left[\mathrm{Ru}\right.$ (bipy) $\left.{ }_{3}\right] \mathrm{Cl}_{2} \cdot 6 \mathrm{H}_{2} \mathrm{O}$ was purchased from Alfa-Aesar, and resolution giving both $\Delta$ and $\Lambda$ enantiomers was performed as previously described, ${ }^{36}$ except that $\mathrm{Na}_{2}\left[\mathrm{Sb}(S, S \text {-tart })_{2}\right](\operatorname{tart}=$ tartrate) was used as the resolving agent in order to optimise the yield of the pure $\Lambda$ enantiomer. Elemental analyses were performed by MEDAC Ltd. at Chobham, UK. For all syntheses of uranyl ion complexes, the mixtures in demineralized water/organic solvent were placed in 10 $\mathrm{mL}$ tightly closed glass vessels and heated at $140{ }^{\circ} \mathrm{C}$ under autogenous pressure. The synthetic conditions are summarized in Table 1.

Table 1. Summary of Synthesis Conditions

\begin{tabular}{cclll}
\hline & \multicolumn{1}{c}{$\begin{array}{c}\text { Carboxylic } \\
\text { Acid }\end{array}$} & $\begin{array}{c}\text { Organic } \\
\text { Cosolvent }\end{array}$ & $\begin{array}{c}\text { Additional } \\
\text { Metal Cation }\end{array}$ & $\begin{array}{c}N \text {-donor } \\
\text { Ligand }\end{array}$ \\
\hline $\mathbf{1}$ & $1,2-\mathrm{H}_{2} \mathrm{PDA}$ & $\mathrm{DMF}$ & $\mathrm{Zn}^{2+}$ & phen \\
$\mathbf{2}$ & $1,4-\mathrm{H}_{2} \mathrm{PDA}$ & $\mathrm{DMF}$ & $\mathrm{Mn}^{2+}$ & bipy \\
$\mathbf{3}$ & $1,3-\mathrm{H}_{2} \mathrm{PDA}$ & acetonitrile & $\mathrm{Zn}^{2+}$ & phen \\
$\mathbf{4}$ & $1,4-\mathrm{H}_{2} \mathrm{PDA}$ & acetonitrile & $\mathrm{Ni}^{2+}$ & phen \\
$\mathbf{5}$ & $1,4-\mathrm{H}_{2} \mathrm{PDA}$ & DMF & $\mathrm{Cu}^{2+}$ & bipy \\
$\mathbf{6}$ & $1,2-\mathrm{H}_{2} \mathrm{PDA}$ & acetonitrile & $\mathrm{Zn}^{2+}$ & phen \\
$\mathbf{7}$ & $1,3-\mathrm{H}_{2} \mathrm{PDA}$ & acetonitrile & $\mathrm{Zn}^{2+}$ & bipy \\
$\mathbf{8}$ & $1,4-\mathrm{H}_{2} \mathrm{PDA}$ & DMF & $\mathrm{Co}^{2+}$ & bipy \\
$\mathbf{9}$ & $1,4-\mathrm{H}_{2} \mathrm{PDA}$ & DMF & $\mathrm{Ni}^{2+}$ & bipy \\
$\mathbf{1 0}$ & $1,4-\mathrm{H}_{2} \mathrm{PDA}$ & DMF & $\mathrm{Ru}^{2+}$ & bipy \\
\hline
\end{tabular}

$\left[\mathrm{UO}_{2}(1,2-P D A)_{2} \mathrm{Zn}(\text { phen })_{2}\right] \cdot 2 \mathrm{H}_{2} \mathrm{O}$ (1). 1,2-Phenylenediacetic acid (20 mg, $0.10 \mathrm{mmol}$ ), $\mathrm{UO}_{2}\left(\mathrm{NO}_{3}\right)_{2} \cdot 6 \mathrm{H}_{2} \mathrm{O}(35 \mathrm{mg}, 0.07 \mathrm{mmol}), \mathrm{Zn}\left(\mathrm{NO}_{3}\right)_{2} \cdot 6 \mathrm{H}_{2} \mathrm{O}(15 \mathrm{mg}, 0.05 \mathrm{mmol})$, and 1,10- 
phenanthroline (27 mg, $0.15 \mathrm{mmol})$ were dissolved in water $(1.2 \mathrm{~mL})$ and DMF $(0.3 \mathrm{~mL})$. Yellow crystals of complex 1 were obtained within ten days (32 mg, 57\% yield based on the acid). Anal. Calcd for $\mathrm{C}_{44} \mathrm{H}_{36} \mathrm{~N}_{4} \mathrm{O}_{12} \mathrm{UZn}$ : C, 47.35; H, 3.25; N, 5.02. Found: C, 48.16; H, 3.15; $\mathrm{N}, 4.89 \%$.

$\left[\cup \mathrm{O}_{2}(1,4-P D A)_{2} \mathrm{Mn}(\text { bipy })_{2}\right] \cdot \mathrm{H}_{2} \mathrm{O}$ (2). 1,4-Phenylenediacetic acid (20 mg, $0.10 \mathrm{mmol}$ ), $\mathrm{UO}_{2}\left(\mathrm{NO}_{3}\right)_{2} \cdot 6 \mathrm{H}_{2} \mathrm{O}(35 \mathrm{mg}, 0.07 \mathrm{mmol}), \mathrm{Mn}\left(\mathrm{NO}_{3}\right)_{2} \cdot 6 \mathrm{H}_{2} \mathrm{O}(15 \mathrm{mg}, 0.05 \mathrm{mmol})$, and 2,2'bipyridine (24 mg, $0.15 \mathrm{mmol})$ were dissolved in water $(0.8 \mathrm{~mL})$ and DMF $(0.2 \mathrm{~mL})$. Yellow crystals of complex 2 were obtained within three days (20 mg, 38\% yield based on the acid). Anal. Calcd for $\mathrm{C}_{40} \mathrm{H}_{34} \mathrm{MnN}_{4} \mathrm{O}_{11} \mathrm{U}$ : C, 46.21; H, 3.30; N, 5.39. Found: C, 46.00; H, 3.23; N, $5.11 \%$

$\left[\mathrm{Zn}(\text { phen })_{3}\right]\left[\left(\cup_{2}\right)_{2}(1,3-P D A)_{3}\right]$ (3). 1,3-Phenylenediacetic acid (20 mg, $\left.0.10 \mathrm{mmol}\right)$, $\mathrm{UO}_{2}\left(\mathrm{NO}_{3}\right)_{2} \cdot 6 \mathrm{H}_{2} \mathrm{O}(35 \mathrm{mg}, 0.07 \mathrm{mmol}), \mathrm{Zn}\left(\mathrm{NO}_{3}\right)_{2} \cdot 6 \mathrm{H}_{2} \mathrm{O}(15 \mathrm{mg}, 0.05 \mathrm{mmol})$, and 1,10phenanthroline $(27 \mathrm{mg}, 0.15 \mathrm{mmol})$ were dissolved in water $(1.2 \mathrm{~mL})$ and acetonitrile $(0.2 \mathrm{~mL})$. Yellow crystals of complex 3 were obtained within one week (30 mg, 52\% yield based on the acid). Elemental analysis results indicate the probable presence of about two extra water molecules. Anal. Calcd for $\mathrm{C}_{66} \mathrm{H}_{48} \mathrm{~N}_{6} \mathrm{O}_{16} \mathrm{U}_{2} \mathrm{Zn}+2 \mathrm{H}_{2} \mathrm{O}: \mathrm{C}, 45.08 ; \mathrm{H}, 2.98 ; \mathrm{N}, 4.78$. Found: $\mathrm{C}$, $44.63 ; \mathrm{H}, 2.86 ; \mathrm{N}, 4.73 \%$.

$\left[\mathrm{Ni}(\text { phen })_{3}\right]\left[\left(\mathrm{UO}_{2}\right)_{2}(1,4-\mathrm{PDA})_{3}\right] \cdot \mathrm{H}_{2} \mathrm{O}$ (4). 1,4-Phenylenediacetic acid (20 mg, $\left.0.10 \mathrm{mmol}\right)$, $\mathrm{UO}_{2}\left(\mathrm{NO}_{3}\right)_{2} \cdot 6 \mathrm{H}_{2} \mathrm{O}(35 \mathrm{mg}, 0.07 \mathrm{mmol}), \mathrm{Ni}\left(\mathrm{NO}_{3}\right)_{2} \cdot 6 \mathrm{H}_{2} \mathrm{O}(15 \mathrm{mg}, 0.05 \mathrm{mmol})$, and 1,10phenanthroline $(27 \mathrm{mg}, 0.15 \mathrm{mmol})$ were dissolved in water $(1.0 \mathrm{~mL})$ and acetonitrile $(0.2 \mathrm{~mL})$. Light pink crystals of complex $\mathbf{4}$ were obtained within ten days, in low yield and mixed with an amorphous powder which was not further characterized. A quantity of pure crystals sufficient for elemental analysis was separated by hand. Anal. Calcd for $\mathrm{C}_{66} \mathrm{H}_{50} \mathrm{~N}_{6} \mathrm{NiO}_{17} \mathrm{U}_{2}$ : C, 45.72; $\mathrm{H}$, $2.91 ; \mathrm{N}, 4.85$. Found: C, 45.63; H, 3.31; N, 4.87\%. 
$\left[\mathrm{Cu}(\text { bipy })_{2}\right]\left[\mathrm{H}_{2} \mathrm{NMe}_{2}\right]\left[\left(\mathrm{UO}_{2}\right)_{2}(1,4-\mathrm{PDA})_{3}\right]$ (5). 1,4-Phenylenediacetic acid (20 mg, 0.10 $\mathrm{mmol}), \mathrm{UO}_{2}\left(\mathrm{NO}_{3}\right)_{2} \cdot 6 \mathrm{H}_{2} \mathrm{O}(35 \mathrm{mg}, 0.07 \mathrm{mmol}), \mathrm{Cu}\left(\mathrm{NO}_{3}\right)_{2} \cdot 2.5 \mathrm{H}_{2} \mathrm{O}(12 \mathrm{mg}, 0.05 \mathrm{mmol})$, and 2,2'-bipyridine (16 mg, $0.10 \mathrm{mmol})$ were dissolved in water $(1.2 \mathrm{~mL})$ and DMF (0.2 mL). Dark orange crystals of complex 5 were obtained within three days ( $26 \mathrm{mg}, 51 \%$ yield based on the acid). Anal. Calcd for $\mathrm{C}_{52} \mathrm{H}_{48} \mathrm{CuN}_{5} \mathrm{O}_{16} \mathrm{U}_{2}$ : C, 40.59; H, 3.14; N, 4.55. Found: C, 40.52; H, 3.06; $\mathrm{N}, 4.38 \%$.

$\left[\mathrm{Zn}(\text { phen })_{3}\right]\left[\left(\mathrm{UO}_{2}\right)_{2}(1,2-P D A)_{3}\right] \cdot 7 \mathrm{H}_{2} \mathrm{O}$ (6). 1,2-Phenylenediacetic acid (20 mg, 0.10 $\mathrm{mmol}), \mathrm{UO}_{2}\left(\mathrm{NO}_{3}\right)_{2} \cdot 6 \mathrm{H}_{2} \mathrm{O}(35 \mathrm{mg}, 0.07 \mathrm{mmol}), \mathrm{Zn}\left(\mathrm{NO}_{3}\right)_{2} \cdot 6 \mathrm{H}_{2} \mathrm{O}(15 \mathrm{mg}, 0.05 \mathrm{mmol})$, and 1,10phenanthroline (27 mg, $0.15 \mathrm{mmol})$ were dissolved in water $(1.2 \mathrm{~mL})$ and acetonitrile $(0.2 \mathrm{~mL})$. Yellow crystals of complex 6 were obtained within one week (28 mg, 45\% yield based on the acid). Upon filtration and drying, the crystals became opaque and striated, indicating desolvation, and this was confirmed by elemental analysis which indicates the loss of about six water molecules. Anal. Calcd for $\mathrm{C}_{66} \mathrm{H}_{62} \mathrm{~N}_{6} \mathrm{O}_{23} \mathrm{U}_{2} \mathrm{Zn}-6 \mathrm{H}_{2} \mathrm{O}$ : C, 45.54; H, 2.90; N, 4.83. Found: C, 45.59; H, 2.88; N, 4.58\%.

$\left[\mathrm{Zn}(\text { bipy })_{3}\right]\left[\left(\mathrm{UO}_{2}\right)_{2}(1,3-P D A)_{3}\right]$ (7). 1,3-Phenylenediacetic acid (20 mg, $\left.0.10 \mathrm{mmol}\right)$, $\mathrm{UO}_{2}\left(\mathrm{NO}_{3}\right)_{2} \cdot 6 \mathrm{H}_{2} \mathrm{O}(35 \mathrm{mg}, 0.07 \mathrm{mmol}), \mathrm{Zn}\left(\mathrm{NO}_{3}\right)_{2} \cdot 6 \mathrm{H}_{2} \mathrm{O}(15 \mathrm{mg}, 0.05 \mathrm{mmol})$, and 2,2'bipyridine $(24 \mathrm{mg}, 0.15 \mathrm{mmol})$ were dissolved in water $(1.0 \mathrm{~mL})$ and acetonitrile $(0.2 \mathrm{~mL})$. Yellow crystals of complex 7 were obtained within two days (16 mg, 29\% yield based on the acid). Anal. Calcd for $\mathrm{C}_{60} \mathrm{H}_{48} \mathrm{~N}_{6} \mathrm{O}_{16} \mathrm{U}_{2} \mathrm{Zn}: \mathrm{C}, 43.66 ; \mathrm{H}, 2.93 ; \mathrm{N}, 5.09$. Found: C, 44.12; H, 2.87; $\mathrm{N}, 5.14 \%$.

$\left[\mathrm{Co}(\text { bipy })_{3}\right]\left[\left(\mathrm{UO}_{2}\right)_{2}(1,4-\mathrm{PDA})_{3}\right]$ (8). 1,4-Phenylenediacetic acid (20 mg, $\left.0.10 \mathrm{mmol}\right)$, $\mathrm{UO}_{2}\left(\mathrm{NO}_{3}\right)_{2} \cdot 6 \mathrm{H}_{2} \mathrm{O}(35 \mathrm{mg}, 0.07 \mathrm{mmol}), \mathrm{Co}\left(\mathrm{NO}_{3}\right)_{2} \cdot 6 \mathrm{H}_{2} \mathrm{O}(15 \mathrm{mg}, 0.05 \mathrm{mmol})$, and 2,2'bipyridine (24 mg, $0.15 \mathrm{mmol})$ were dissolved in water $(1.0 \mathrm{~mL})$ and DMF (0.2 mL). Light yellow-orange crystals of complex 8 were obtained within three days (25 mg, $46 \%$ yield based 
on the acid). Anal. Calcd for $\mathrm{C}_{60} \mathrm{H}_{48} \mathrm{CoN}_{6} \mathrm{O}_{16} \mathrm{U}_{2}: \mathrm{C}, 43.83 ; \mathrm{H}, 2.94 ; \mathrm{N}, 5.11$. Found: $\mathrm{C}, 43.72$; $\mathrm{H}, 2.98 ; \mathrm{N}, 4.92 \%$.

$\left[\mathrm{Ni}(\text { bipy })_{3}\right]\left[\left(\cup_{2}\right)_{2}(1,4-P D A)_{3}\right]$ (9). 1,4-Phenylenediacetic acid (20 mg, $\left.0.10 \mathrm{mmol}\right)$, $\mathrm{UO}_{2}\left(\mathrm{NO}_{3}\right)_{2} \cdot 6 \mathrm{H}_{2} \mathrm{O}(35 \mathrm{mg}, 0.07 \mathrm{mmol}), \mathrm{Ni}\left(\mathrm{NO}_{3}\right)_{2} \cdot 6 \mathrm{H}_{2} \mathrm{O}(15 \mathrm{mg}, 0.05 \mathrm{mmol})$, and 2,2'bipyridine (24 mg, $0.15 \mathrm{mmol})$ were dissolved in water $(1.0 \mathrm{~mL})$ and DMF (0.2 mL). Light orange crystals of complex 9 were obtained within four days (46 mg, 84\% yield based on the acid). Elemental analysis results indicate the probable presence of about one extra water molecule. Anal. Calcd for $\mathrm{C}_{60} \mathrm{H}_{48} \mathrm{~N}_{6} \mathrm{NiO}_{16} \mathrm{U}_{2}+\mathrm{H}_{2} \mathrm{O}$ : C, 43.37; H, 3.03; N, 5.06. Found: $\mathrm{C}$, $43.32 ; \mathrm{H}, 3.03 ; \mathrm{N}, 4.84 \%$.

$\left\{\Lambda-\left[R u(\text { bipy })_{3}\right]\right\}\left[\left(\cup O_{2}\right)_{2}(1,4-P D A)_{3}\right]$ (10). 1,4-Phenylenediacetic acid (10 mg, $\left.0.05 \mathrm{mmol}\right)$, $\mathrm{UO}_{2}\left(\mathrm{NO}_{3}\right)_{2} \cdot 6 \mathrm{H}_{2} \mathrm{O}(17 \mathrm{mg}, 0.034 \mathrm{mmol})$, and $\Lambda$-[Ru(bipy $\left.)_{3}\right] \mathrm{Cl}_{2} \cdot 6 \mathrm{H}_{2} \mathrm{O}(19 \mathrm{mg}, 0.025 \mathrm{mmol})$ were dissolved in water $(0.5 \mathrm{~mL})$ and DMF $(0.2 \mathrm{~mL})$. Dark orange crystals of complex $\mathbf{1 0}$ were obtained within four days in low yield and mixed with yellow crystals of $\left[\mathrm{H}_{2} \mathrm{NMe}_{2}\right]_{2}\left[\left(\mathrm{UO}_{2}\right)_{2}(1,4-\mathrm{PDA})_{3}\right]$. A quantity of pure crystals of $\mathbf{1 0}$ sufficient for elemental analysis was separated by hand. Elemental analysis results indicate the probable presence of about two extra water molecules. Anal. Calcd for $\mathrm{C}_{60} \mathrm{H}_{48} \mathrm{~N}_{6} \mathrm{O}_{16} \mathrm{RuU}_{2}+2 \mathrm{H}_{2} \mathrm{O}$ : C, 41.85; H, 3.04; N, 4.88. Found: C, 42.09; H, 3.06; N, 4.73\%.

Crystallography. The data were collected at 100(2) K on a Nonius Kappa-CCD area detector diffractometer ${ }^{37}$ using graphite-monochromated Mo K $\alpha$ radiation $(\lambda=0.71073 \AA)$. The crystals were introduced into glass capillaries with a protective coating of Paratone-N oil (Hampton Research). The unit cell parameters were determined from ten frames, then refined on all data. The data (combinations of $\varphi$ - and $\omega$-scans with a minimum redundancy of at least 4 for $90 \%$ of the reflections) were processed with HKL2000. ${ }^{38}$ Absorption effects were corrected empirically with the program SCALEPACK. ${ }^{38}$ The structures were solved by intrinsic phasing 
with SHELXT, ${ }^{39}$ expanded by subsequent difference Fourier synthesis and refined by fullmatrix least-squares on $F^{2}$ with SHELXL ${ }^{40}$ implemented in ShelXle. ${ }^{41}$ All non-hydrogen atoms were refined with anisotropic displacement parameters. When present, the hydrogen atoms bound to oxygen and nitrogen atoms were retrieved from difference Fourier maps, except for those of one water solvent molecule in $\mathbf{4}$ and $\mathbf{6}$, and the carbon-bound hydrogen atoms were introduced at calculated positions. All hydrogen atoms were treated as riding atoms with an isotropic displacement parameter equal to 1.2 times that of the parent atom $\left(1.5\right.$ for $\mathrm{CH}_{3}$, with optimized geometry). In complexes $\mathbf{8}$ and $\mathbf{9}$, two bipy ligands are disordered over two positions related by symmetry. The structure of complex 7 was refined as an inversion twin [Flack parameter 0.527(9)], while that of complex $\mathbf{1 0}$ contains the pure enantiomeric form of the counterion [Flack parameter 0.011(11)]. Crystal data and structure refinement parameters are given in Table 2. The molecular plots were drawn with ORTEP-3, ${ }^{42}$ and the polyhedral representations with VESTA. ${ }^{43}$ The topological analyses and nodal representations were made with TOPOS. ${ }^{44}$

Table 2. Crystal Data and Structure Refinement Details

\begin{tabular}{|c|c|c|c|c|c|}
\hline & 1 & 2 & 3 & 4 & 5 \\
\hline chemical formula & $\mathrm{C}_{44} \mathrm{H}_{36} \mathrm{~N}_{4} \mathrm{O}_{12} \mathrm{UZn}$ & $\mathrm{C}_{40} \mathrm{H}_{34} \mathrm{MnN}_{4} \mathrm{O}_{11} \mathrm{U}$ & $\mathrm{C}_{66} \mathrm{H}_{48} \mathrm{~N}_{6} \mathrm{O}_{16} \mathrm{U}_{2} \mathrm{Zn}$ & $\mathrm{C}_{66} \mathrm{H}_{50} \mathrm{~N}_{6} \mathrm{NiO}_{17} \mathrm{U}_{2}$ & $\mathrm{C}_{52} \mathrm{H}_{48} \mathrm{CuN}_{5} \mathrm{O}_{16} \mathrm{U}_{2}$ \\
\hline$M\left(\mathrm{~g} \mathrm{~mol}^{-1}\right)$ & 1116.17 & 1039.68 & 1722.53 & 1733.89 & 1538.55 \\
\hline cryst syst & triclinic & triclinic & monoclinic & triclinic & monoclinic \\
\hline space group & $P \overline{1}$ & $P \overline{1}$ & $P 2_{1} / c$ & $P \overline{1}$ & $P 2 / n$ \\
\hline$a(\AA)$ & $9.8624(4)$ & $10.4013(5)$ & $14.8585(4)$ & $10.4497(3)$ & $17.1560(7)$ \\
\hline$b(\AA)$ & $13.0713(7)$ & $13.6462(7)$ & $14.8241(3)$ & $14.3275(9)$ & $7.9076(4)$ \\
\hline$c(\AA)$ & $17.1515(9)$ & $15.1161(4)$ & $27.4020(8)$ & $22.2411(13)$ & $20.6059(7)$ \\
\hline$\alpha(\operatorname{deg})$ & $72.615(2)$ & $68.320(3)$ & 90 & $104.985(2)$ & 90 \\
\hline$\beta(\operatorname{deg})$ & $88.723(3)$ & $75.981(3)$ & $100.6245(17)$ & $90.812(3)$ & $107.411(3)$ \\
\hline$\gamma(\operatorname{deg})$ & $74.185(3)$ & $86.527(2)$ & 90 & $95.318(3)$ & 90 \\
\hline$V\left(\AA^{3}\right)$ & $2025.98(18)$ & $1933.40(15)$ & $5932.2(3)$ & $3200.3(3)$ & $2667.4(2)$ \\
\hline$Z$ & 2 & 2 & 4 & 2 & 2 \\
\hline reflns collcd & 113905 & 105162 & 263221 & 164616 & 93597 \\
\hline indep reflns & 7653 & 7345 & 11248 & 12161 & 5053 \\
\hline obsd reflns $[I>2 \sigma(I)]$ & 7122 & 6765 & 9810 & 9348 & 4375 \\
\hline$R_{\text {int }}$ & 0.055 & 0.051 & 0.060 & 0.074 & 0.048 \\
\hline params refined & 559 & 514 & 820 & 829 & 345 \\
\hline$R_{1}$ & 0.022 & 0.022 & 0.033 & 0.036 & 0.029 \\
\hline$w R_{2}$ & 0.055 & 0.051 & 0.079 & 0.090 & 0.073 \\
\hline$S$ & 1.012 & 1.052 & 1.100 & 0.966 & 1.061 \\
\hline$\Delta \rho_{\min }\left(\mathrm{e} \AA^{-3}\right)$ & -1.66 & -1.33 & -1.07 & -2.57 & -1.21 \\
\hline$\Delta \rho_{\max }\left(\mathrm{e} \AA^{-3}\right)$ & 0.85 & 0.69 & 1.58 & 1.94 & 1.01 \\
\hline
\end{tabular}




\begin{tabular}{|c|c|c|c|c|c|}
\hline & 6 & 7 & 8 & 9 & 10 \\
\hline chemical formula & $\mathrm{C}_{66} \mathrm{H}_{62} \mathrm{~N}_{6} \mathrm{O}_{23} \mathrm{U}_{2} \mathrm{Zn}$ & $\mathrm{C}_{60} \mathrm{H}_{48} \mathrm{~N}_{6} \mathrm{O}_{16} \mathrm{U}_{2} \mathrm{Zn}$ & $\mathrm{C}_{60} \mathrm{H}_{48} \mathrm{CoN}_{6} \mathrm{O}_{16} \mathrm{U}_{2}$ & $\mathrm{C}_{60} \mathrm{H}_{48} \mathrm{~N}_{6} \mathrm{NiO}_{16} \mathrm{U}_{2}$ & $\mathrm{C}_{60} \mathrm{H}_{48} \mathrm{~N}_{6} \mathrm{O}_{16} \mathrm{RuU}_{2}$ \\
\hline$M\left(\mathrm{~g} \mathrm{~mol}^{-1}\right)$ & 1848.64 & 1650.47 & 1644.03 & 1643.81 & 1686.17 \\
\hline cryst syst & triclinic & orthorhombic & orthorhombic & orthorhombic & orthorhombic \\
\hline space group & $P_{1}$ & $P n a 2_{1}$ & $\mathrm{Cmcm}$ & $\mathrm{Cmcm}$ & $C 222_{1}$ \\
\hline$a(\AA)$ & $14.1948(9)$ & $18.1452(8)$ & $21.4452(11)$ & $21.4844(9)$ & $19.5684(10)$ \\
\hline$b(\AA)$ & $14.6335(5)$ & $22.1979(9)$ & $19.5031(10)$ & $19.4449(8)$ & $21.4080(11)$ \\
\hline$c(\AA)$ & $18.5407(10)$ & $13.9147(3)$ & $13.8426(4)$ & $13.8633(3)$ & $13.9395(4)$ \\
\hline$\alpha(\operatorname{deg})$ & $66.900(3)$ & 90 & 90 & 90 & 90 \\
\hline$\beta(\mathrm{deg})$ & $73.680(3)$ & 90 & 90 & 90 & 90 \\
\hline$\gamma(\mathrm{deg})$ & $71.404(3)$ & 90 & 90 & 90 & 90 \\
\hline$V\left(\AA^{3}\right)$ & $3303.4(3)$ & $5604.6(4)$ & $5789.6(5)$ & $5791.6(4)$ & $5839.5(5)$ \\
\hline$Z$ & 2 & 4 & 4 & 4 & 4 \\
\hline reflns collcd & 181109 & 109404 & 51105 & 84086 & 80718 \\
\hline indep reflns & 12543 & 10310 & 2952 & 2950 & 5542 \\
\hline obsd reflns $[I>2 \sigma(I)]$ & 10120 & 8535 & 2299 & 2770 & 5075 \\
\hline$R_{\text {int }}$ & 0.057 & 0.028 & 0.036 & 0.014 & 0.027 \\
\hline params refined & 883 & 767 & 263 & 263 & 385 \\
\hline$R_{1}$ & 0.031 & 0.034 & 0.032 & 0.024 & 0.034 \\
\hline$w R_{2}$ & 0.074 & 0.082 & 0.071 & 0.058 & 0.099 \\
\hline$S$ & 1.022 & 0.986 & 0.989 & 1.166 & 1.054 \\
\hline$\Delta \rho_{\min }\left(\mathrm{e} \AA^{-3}\right)$ & -1.45 & -1.11 & -1.10 & -0.81 & -1.52 \\
\hline$\Delta \rho_{\max }\left(\mathrm{e} \AA^{-3}\right)$ & 1.70 & 0.84 & 0.58 & 0.89 & 0.90 \\
\hline
\end{tabular}

Luminescence Measurements. Emission spectra were recorded on solid samples using a Horiba-Jobin-Yvon IBH FL-322 Fluorolog 3 spectrometer equipped with a $450 \mathrm{~W}$ xenon arc lamp, double-grating excitation and emission monochromator $(2.1 \mathrm{~nm} / \mathrm{mm}$ of dispersion; 1200 grooves $/ \mathrm{mm}$ ) and a TBX-04 single photon-counting detector. The powdered compounds were pressed to the wall of a quartz tube, and the measurements were performed using the right-angle mode. An excitation wavelength of $420 \mathrm{~nm}$, a commonly used point although only part of a broad manifold, was used in all cases and the emission was monitored between 450 and 650 nm. The quantum yield measurements were performed by using a Hamamatsu Quantaurus C11347 absolute photoluminescence quantum yield spectrometer and exciting the samples between 300 and $400 \mathrm{~nm}$.

\section{RESULTS AND DISCUSSION}

Synthesis. Crystals of complexes 1-10 were grown under solvo-hydrothermal conditions, at a temperature of $140{ }^{\circ} \mathrm{C}$, and the crystals were deposited directly from the pressurized and heated reaction mixtures and not as a result of subsequent cooling. Syntheses were attempted in all cases with either $N, N$-dimethylformamide or acetonitrile cosolvents, one or the other being more successful in each particular case (DMF for 1, 2, 5, and 8-10, and 
acetonitrile for $3,4,6$ and 7), for no obvious reason. Only in the case of 5 has the organic solvent a direct bearing on the product formed, as the lattice includes dimethylammonium cations generated in situ from DMF hydrolysis, as frequently observed; in this complex, the $\mathrm{Cu}^{\mathrm{II}}$ ions originally present have been reduced to $\mathrm{Cu}^{\mathrm{I}}$, an occurrence previously encountered, ${ }^{26,45,46}$ and presumably due to stabilization of the lower oxidation state by bipy ligands. Complex $\mathbf{1 0}$ was obtained together with the uranium-only complex $\left[\mathrm{H}_{2} \mathrm{NMe}_{2}\right]_{2}\left[\left(\mathrm{UO}_{2}\right)_{2}(1,4-\mathrm{PDA})_{3}\right]$, which will be presented elsewhere and contains also dimethylammonium cations; unfortunately, replacement of DMF by acetonitrile in this case gave no exploitable crystalline species. The uranium/diacetate ligand ratio was 7:10 in all cases, so as to favour the formation of an anionic species, and the expected ratio of 2:3 is retained in all complexes but $\mathbf{1}$ and $\mathbf{2}$, for which it is 1:2, with the transition metal included in the neutral complex, and not present as a separate counterion as in all other cases. Thus, in the majority of cases the stoichiometry of the final species and the incorporation of the counterion matches well what was intended, resulting in this system being suitable for an investigation of the effects of the ligand geometry and nature of the counterion in compounds that are otherwise closely comparable. In most cases, the ratio of aza-aromatic ligand to transition metal ion is also that of the reaction mixtures, the choice of this ratio being governed by the intention of generating a coordinately saturated $\left[\mathrm{M}(\mathrm{L})_{3}\right]^{2+}$ species. While the presence of an $\left[\mathrm{Mn}(\text { bipy })_{2}\right]^{2+}$ derivative in complex $\mathbf{2}$ is consistent with the relatively low stability (at $298 \mathrm{~K}$ ) of $\left[\mathrm{Mn}(\text { bipy })_{3}\right]^{2+}$ compared to that of other dipositive transition metal analogues, ${ }^{47}$ the fact that complex 1 contains a $\left[\mathrm{Zn}(\text { phen })_{2}\right]^{2+}$ moiety while complex $\mathbf{6}$ contains $\left[\mathrm{Zn}(\text { phen })_{3}\right]^{2+}$ despite the ratio $\mathrm{Zn}$ :phen being $1: 3$ in both preparative mixtures, indicates that simple solubility differences may be determinant (the two solvent mixtures being different).

Crystal Structures. The complex $\left[\mathrm{UO}_{2}(1,2-\mathrm{PDA})_{2} \mathrm{Zn}(\text { phen })_{2}\right] \cdot 2 \mathrm{H}_{2} \mathrm{O}$ (1) is a heterometallic species in which the unique uranium atom is chelated by three carboxylate 
groups giving a hexagonal bipyramidal environment [U-O(oxo) $1.7770(17)$ and $1.7777(17) \AA$, $\mathrm{U}-\mathrm{O}$ (carboxylate) $2.4367(17)-2.5036(17) \AA$ ] , and the $\mathrm{Zn}^{\mathrm{II}}$ cation is chelated by one carboxylate and two phen molecules, in a chiral octahedral environment distorted due to the small bite of the carboxylate ligand (Figure 1). The two inequivalent 1,2-PDA ${ }^{2-}$ ligands are bis-chelating (bis- $\kappa^{2} O, O^{\prime}$ mode) and bound to either two uranyl or one uranyl and one zinc(II) cations. These two ligands assume different conformations, both completely lacking symmetry and thus being chiral, the former having one carboxylate group straddling the aromatic plane and the other directed sideways, while the two carboxylate groups of the latter are oriented to opposite sides of the plane (a form denoted 'trans' hereafter). The uranium atoms and their bridging ligands form a one-dimensional (1D) coordination polymer directed along [100], to which the $\mathrm{Zn}$ (phen $)_{2}{ }^{2+}$ moieties are attached as pendent, decorating groups. The uranium atoms can be considered to lie in slightly rippled planes parallel to (010), with the shortest separation between uranium atoms in different chains being 7.3015(4) A. Chains with such a separation are homochiral and enantiomeric, with both the configuration of the $\left[\mathrm{Zn}(\mathrm{phen})_{2}\left(\mathrm{RCO}_{2}\right)\right]^{+}$units and of the two inequivalent ligand units in each chain being related by inversion. Analysis of short contacts with PLATON ${ }^{48}$ reveals four possible parallel-displaced $\pi \cdots \pi$ interactions involving the central and lateral rings of the phen molecules pertaining to adjacent (heterochiral) chains,

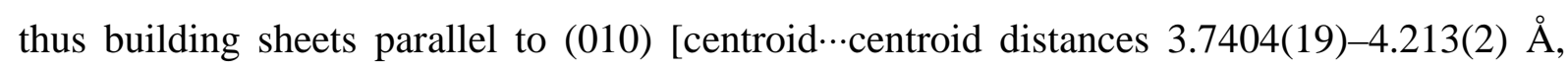
dihedral angles $0-3.96(14)^{\circ}$ ], as well as three $\mathrm{CH} \cdots \pi$ interactions between protons and aromatic

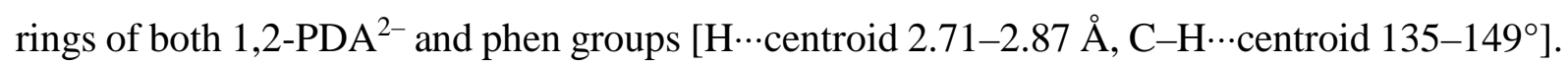




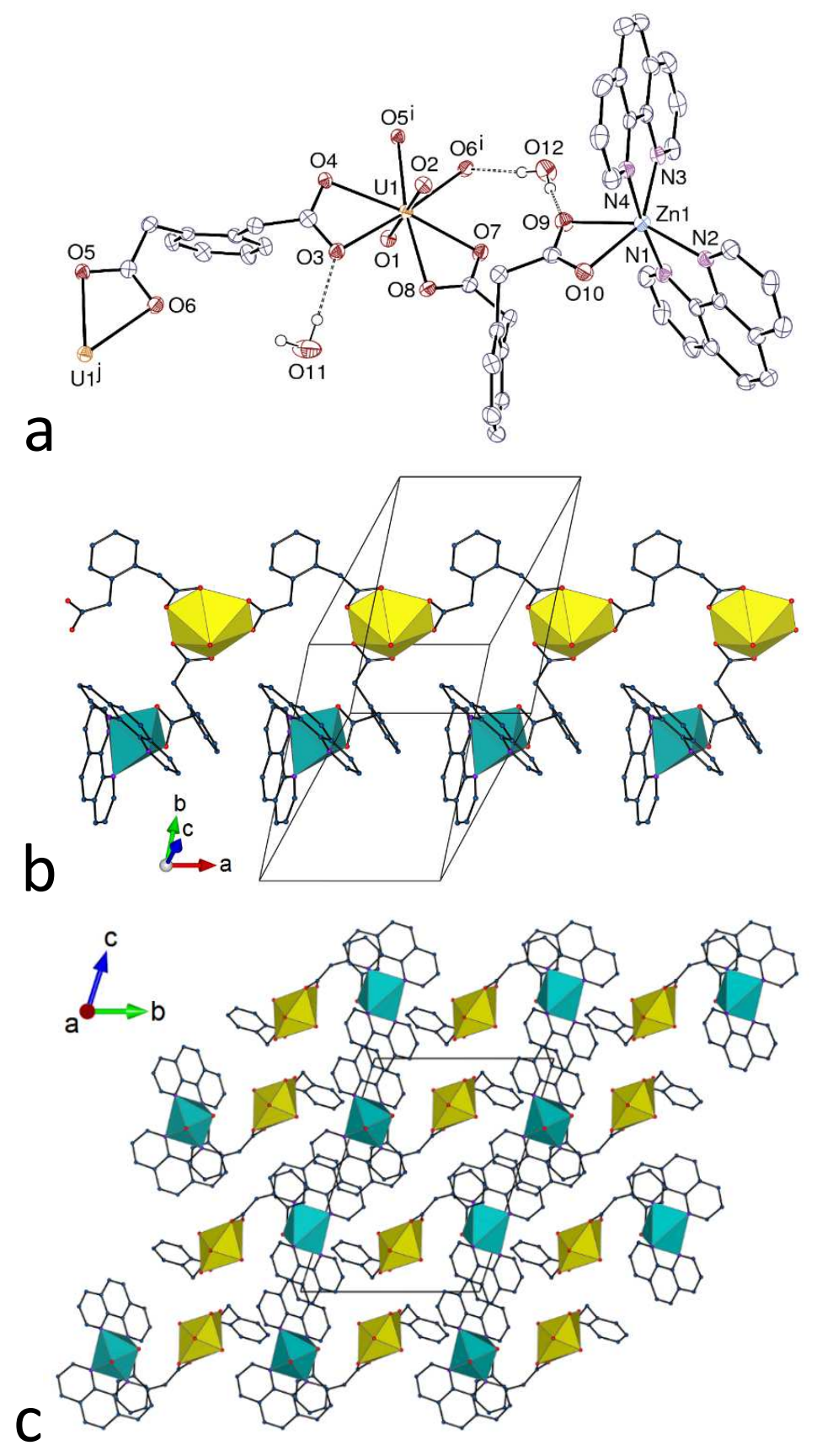

Figure 1. (a) View of compound 1. Displacement ellipsoids are drawn at the 50\% probability level. Carbon-bound hydrogen atoms are omitted and hydrogen bonds are shown as dashed lines. Symmetry codes: $\mathrm{i}=x+1, y, z ; \mathrm{j}=x$ $-1, y, z$. (b) View of the 1D coordination polymer. (c) Packing with chains viewed end-on. Uranium coordination polyhedra are colored yellow and those of zinc(II) green, and solvent molecules and hydrogen atoms are omitted in the last two views.

The lattice water molecules are hydrogen bonded to one another and to carboxylate groups of the same chain $\left[\mathrm{O} \cdots \mathrm{O} 2.780(3)-2.931(3) \AA\right.$, $\left.\mathrm{O}-\mathrm{H} \cdots \mathrm{O} 170-174^{\circ}\right]$, and several $\mathrm{CH} \cdots \mathrm{O}$ hydrogen 
bonds $s^{49,50}$ are present as well, and appear prominently on the Hirshfeld surfaces (HSs) ${ }^{51}$ calculated with CrystalExplorer (version 3.1). ${ }^{52}$ The Kitaigorodski packing index (KPI) calculated with PLATON, ${ }^{48} 0.70$, is indicative of a compact packing with no porosity.

The complex $\left[\mathrm{UO}_{2}(1,4-\mathrm{PDA})_{2} \mathrm{Mn}(\text { bipy })_{2}\right] \cdot \mathrm{H}_{2} \mathrm{O}(2)$ presents some similarities with $\mathbf{1}$ in the sense that, here also, the tris-chelated uranyl cation [U-O(oxo) 1.7747(19) and 1.7756(19) $\AA$, U$\mathrm{O}$ (carboxylate) $2.4471(18)-2.494(2) \AA]$ and the $\mathrm{Mn}^{\mathrm{II}}$ cation pertain to the same neutral coordination polymer (Figure 2). The latter, octahedrally coordinated cation is chelated by two bipy molecules and bound to two carboxylate oxygen atoms from two 1,4-PDA ${ }^{2-}$ ligands, forming a centrosymmetric, carboxylate-bridged $\left(\mu_{2}-\kappa^{1} O ; \kappa^{1} O^{\prime}\right)$ binuclear unit in which the $\mathrm{Mn}^{\mathrm{II}}$ centres are enantiomeric, as are the attached 1,4-PDA ${ }^{2-}$ ligands, although their conformation, with the carboxylate groups disposed to opposite sides of the aromatic ring (trans), is only slightly distorted from centrosymmetry. The second of the two inequivalent ligand units, with its two carboxylate groups pointing toward the same side of the aromatic ring (a form denoted 'cis' hereafter), in a conformation which is only slightly distorted from one with a plane of symmetry, connects two uranyl cations as in $\mathbf{1}$, but here a centrosymmetric 2:2 ring is formed. A $1 \mathrm{D}$ coordination polymer parallel to [22i] is thus formed here also, but one to the formation of which both cations contribute, and which displays an alternation of uranyl and manganese dimeric units. It is also unlike complex $\mathbf{1}$ in that each polymer strand contains both enantiomers of each chiral component, so that it is effectively racemic. Only one possible interchain $\pi \cdots \pi$ interaction between 1,4-PDA ${ }^{2-}$ and bipy rings may be present [centroid $\cdots$ centroid 4.4023(18) $\AA$, dihedral angle $\left.36.97(15)^{\circ}\right]$, as well as two $\mathrm{CH} \cdots \pi$ contacts $[\mathrm{H} \cdots$ centroid 2.56 and $2.92 \AA$, C$\mathrm{H} \cdots$ centroid 159 and $160^{\circ}$ ], but the $\mathrm{CH} \cdots \mathrm{O}$ hydrogen bonds involving protons of the bipy molecules and oxo or carboxylato acceptors appear to be dominant from examination of the HS $\left[\mathrm{C} \cdots \mathrm{O} 3.095(4)-3.455(4) \AA, \mathrm{C}-\mathrm{H} \cdots \mathrm{O} 118-161^{\circ}\right]$. In this case also, no porosity is present (KPI 0.69). 


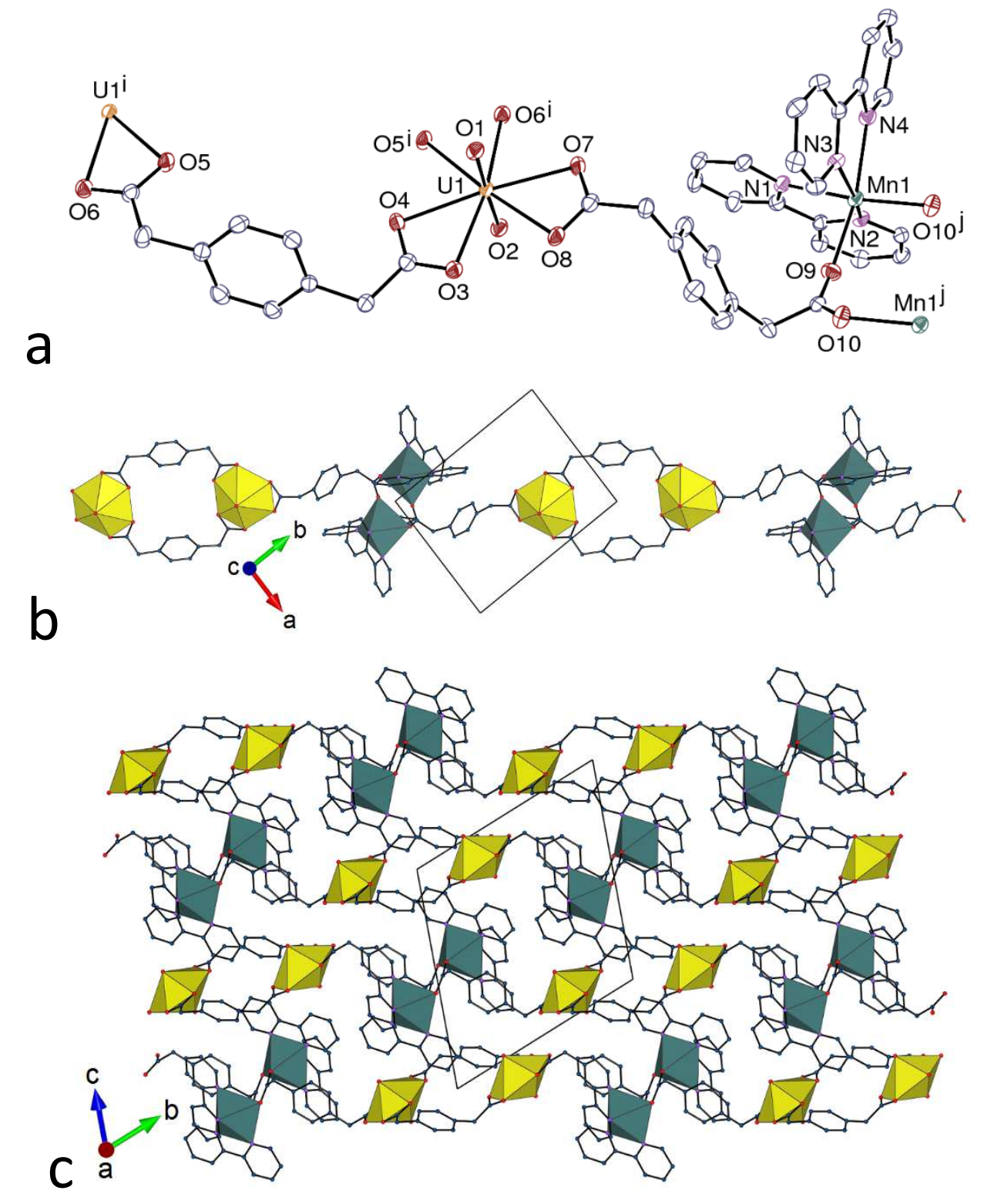

Figure 2. (a) View of compound 2. Displacement ellipsoids are drawn at the $50 \%$ probability level. Symmetry codes: $\mathrm{i}=2-x, 2-y,-z ; \mathrm{j}=-x,-y, 1-z$. (b) View of the 1D coordination polymer. (c) View of the packing. Solvent molecules and hydrogen atoms are omitted in all views.

In the presence of $\mathrm{Zn}^{\mathrm{II}}$ cations and phen donors, the 1,3-PDA ${ }^{2-}$ ligand gives the uranyl complex $\left[\mathrm{Zn}(\text { phen })_{3}\right]\left[\left(\mathrm{UO}_{2}\right)_{2}(1,3-\mathrm{PDA})_{3}\right](3)$, very different from that containing $1,2-\mathrm{PDA}^{2-}$ (1). The two complexes were obtained in the presence of different organic cosolvents, which may have an effect on the reaction outcome, but the difference in the geometry of the dicarboxylate ligand is most probably paramount. As in all the following compounds in this 
series, the transition metal-containing counterion is not directly coordinated to the anionic uranyl complex and its effects are thus essentially those of a structure-directing species. The two uranyl cations in the asymmetric unit are both tris-chelated [U-O(oxo) 1.767(3)-1.778(3) A, U-O(carboxylate) 2.436(4)-2.498(3) $̊$ ], and all three inequivalent ligands are bis-chelating and with their two carboxylate groups on either side of the aromatic rings (trans, although with slightly variable tilting), once again in chiral conformations (Figure 3). This connectivity gives rise to the formation of a two-dimensional (2D) network parallel to (10-2) which has the $\left\{6^{3}\right\}$ point (Schläfli) symbol and the common honeycomb (hcb) topological type. These layers are associated in twos so as to define channels directed along [010], in which the counterions are located. Both $\Delta$ and $\Lambda$ enantiomers of $\left[\mathrm{Zn}(\mathrm{phen})_{3}\right]^{2+}$ (in equal numbers) are associated with each double layer, a given enantiomer occupying a cavity in the double layer which has itself a chirality (specific to the cation) defined by the chirality of the three different ligands forming its walls, each sheet being racemic. Some $\pi \cdots \pi$ interactions may be present between $1,3-\mathrm{PDA}^{2-}$

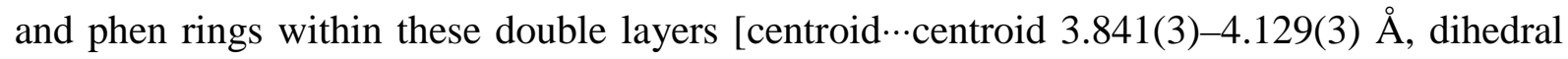
angles $\left.13.0(3)-27.8(2)^{\circ}\right]$, as well as some $\mathrm{CH} \cdots \pi$ contacts involving these two ligands as donors

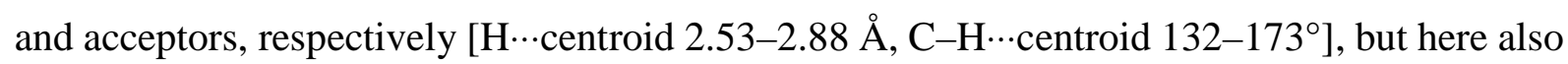
$\mathrm{CH} \cdots \mathrm{O}$ hydrogen bonding is the most prominent association mode between the two components [C‥O 3.108(6)-3.494(7) $\left.\AA, \mathrm{C}-\mathrm{H} \cdots \mathrm{O} 134-171^{\circ}\right]$. The double layers are tightly packed and the KPI amounts to 0.70 . 

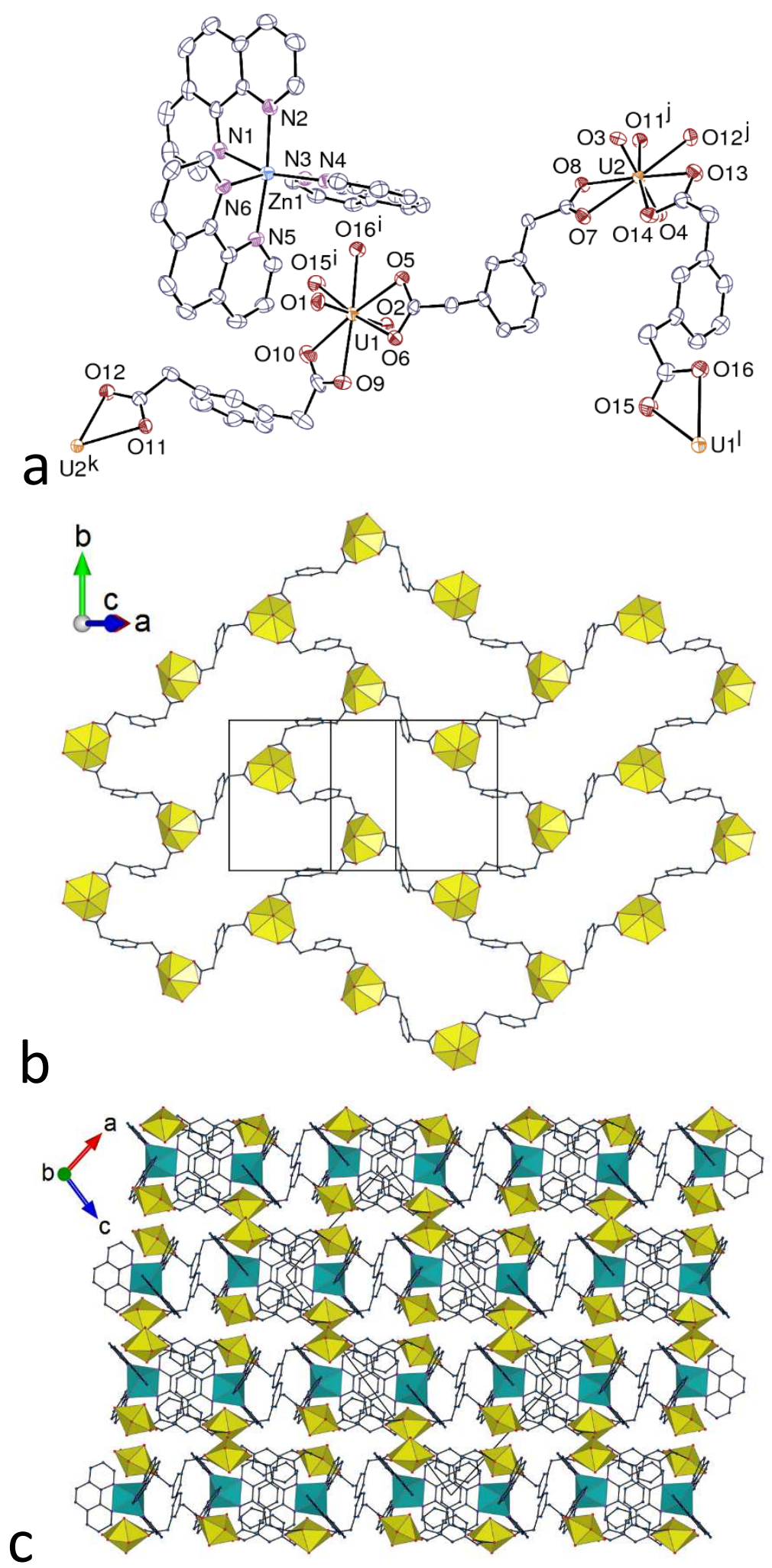

Figure 3. (a) View of compound 3. Displacement ellipsoids are drawn at the $50 \%$ probability level. Symmetry codes: $\mathrm{i}=x, y+1, z ; \mathrm{j}=x+1,3 / 2-y, z+1 / 2 ; \mathrm{k}=x-1,3 / 2-y, z-1 / 2 ; 1=x, y-1, z$. (b) View of the 2D network. (c) View of the packing with double layers viewed edge-on. Hydrogen atoms are omitted in all views. 
With the replacement of $\mathrm{Zn}^{\mathrm{II}}$ by $\mathrm{Ni}^{\mathrm{II}}, 1,4-\mathrm{PDA}^{2-}$ gives the complex $\left[\mathrm{Ni}(\text { phen })_{3}\right]\left[\left(\mathrm{UO}_{2}\right)_{2}(1,4-\mathrm{PDA})_{3}\right] \cdot \mathrm{H}_{2} \mathrm{O}(\mathbf{4})$. Here also, the two independent uranyl ions are chelated by three carboxylate groups [U-O(oxo) 1.763(4)-1.773(3) $\AA$, U-O(carboxylate) 2.407(4)-2.506(3) $\AA$ ], and the three inequivalent 1,4-PDA ${ }^{2-}$ ligands (two of them centrosymmetric and thus in an achiral conformation) are all bis-chelating (Figure 4). All ligands have their carboxylate groups in trans positions, but for that containing O13-O16, which is cis and forms a centrosymmetric 2:2 dinuclear ring analogous to that found in complex 2. The 2D assembly formed, parallel to (103), can be viewed as topologically equivalent to an enlarged honeycomb network in which one 2:2 dimer and one extra dicarboxylate connector are inserted into two links, thus giving very elongated cells. The corrugated sheets are stacked so as to form channels directed along the [010] axis and containing the counterions. Each elongated cell can be regarded as associated with four $\left[\mathrm{Ni}(\mathrm{phen})_{3}\right]^{2+}$ cations, present as $\Delta, \Delta$ and $\Lambda, \Lambda$ pairs, so that once again the crystal is a racemic material. Three $\pi \cdots \pi$ interactions may be

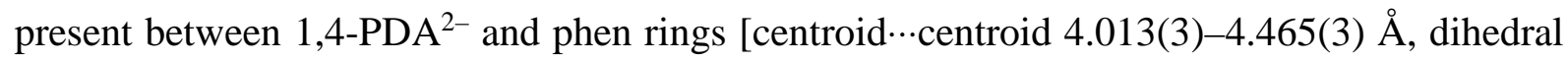
angles $\left.8.5(3)-25.9(3)^{\circ}\right]$. Several $\mathrm{CH} \cdots \pi$ contacts involving a mixture of protons and aromatic rings from the two aromatic ligands $\left[\mathrm{H} \cdots\right.$ centroid $2.66-2.98 \AA$, $\mathrm{C}-\mathrm{H} \cdots$ centroid $\left.132-173^{\circ}\right]$ and $\mathrm{CH} \cdots \mathrm{O}$ hydrogen bonds involving protons from both ligands and oxo or carboxylato acceptors $\left[\mathrm{C} \cdots \mathrm{O} 3.170(7)-3.467(7) \AA, \mathrm{C}-\mathrm{H} \cdots \mathrm{O} 135-159^{\circ}\right]$ are also found. Some voids are present in the lattice (KPI 0.65), although no clearly defined open channel is apparent. 

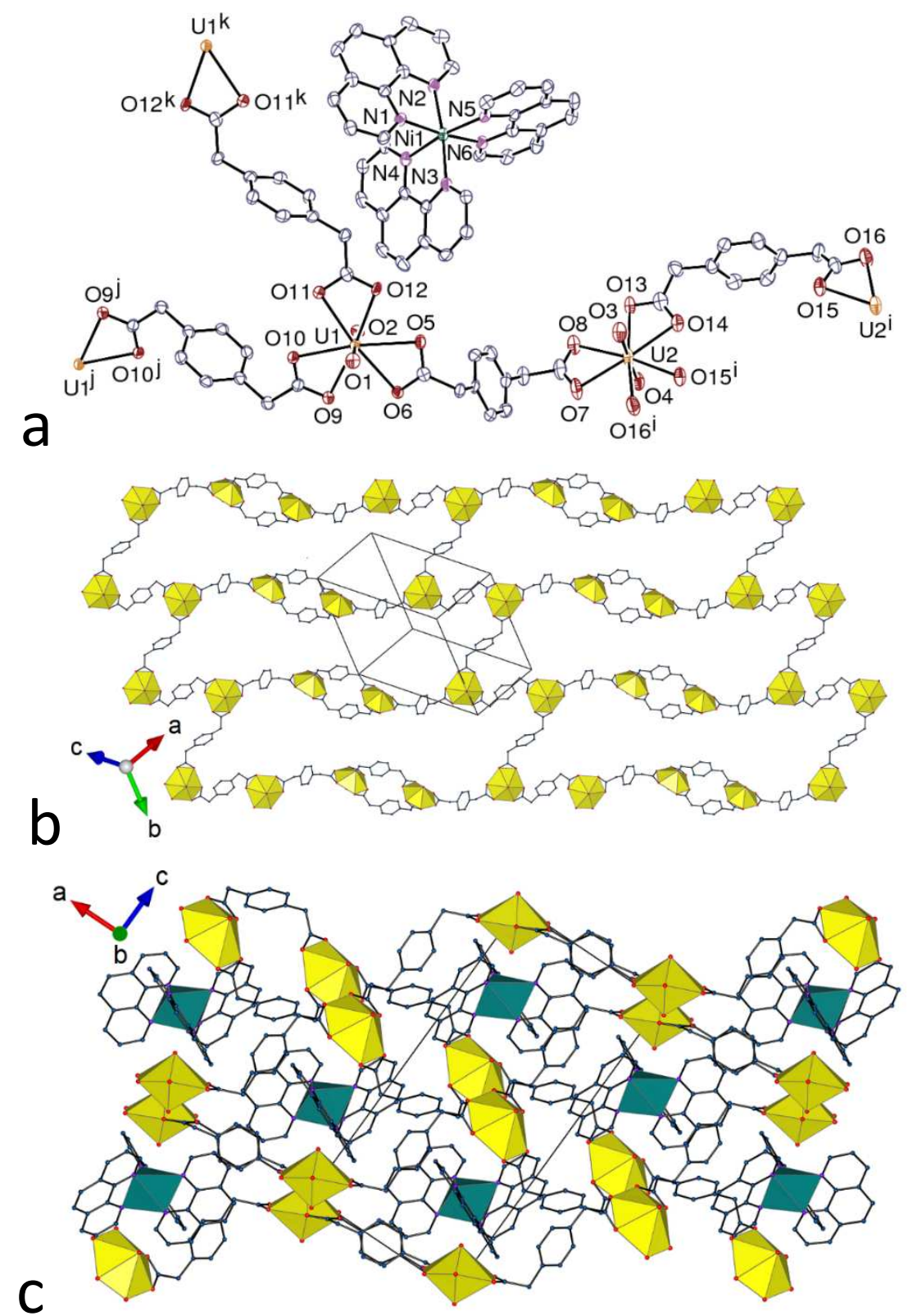

Figure 4. (a) View of compound 4. Displacement ellipsoids are drawn at the 50\% probability level. Symmetry codes: $\mathrm{i}=2-x, 1-y, 1-z ; \mathrm{j}=-x-1,-y, 2-z ; \mathrm{k}=-x-1,1-y, 2-z$. (b) View of the 2D network. (c) View of the packing with layers viewed edge-on. Solvent molecules and hydrogen atoms are omitted in all views.

The same 1,4 isomer of the diacetate ligand, when used in the presence of $\mathrm{Cu}^{\mathrm{II}}$ ions, bipy donors and DMF as cosolvent, gives the complex $\left[\mathrm{Cu}(\text { bipy })_{2}\right]\left[\mathrm{H}_{2} \mathrm{NMe}_{2}\right]\left[\left(\mathrm{UO}_{2}\right)_{2}(1,4-\right.$ PDA) $\left.{ }_{3}\right](5)$, containing reduced $\mathrm{Cu}^{\mathrm{I}}$ cations and dimethylammonium cations formed in situ. The charge and stoichiometry of the anionic uranyl complex are the same as in $\mathbf{4}$, but replacement of the $\left[\mathrm{Ni}(\text { phen })_{3}\right]^{2+}$ counterions by a mixture of $\mathrm{H}_{2} \mathrm{NMe}_{2}{ }^{+}$and slightly flattened tetrahedral 
$\left[\mathrm{Cu}(\text { bipy })_{2}\right]^{+}$cations (the preferred coordination geometry for $\mathrm{Cu}^{\mathrm{I}}$ cations ${ }^{53}$ ) has significant consequences on the complex topology. The unique uranyl cation is once again tris-chelated

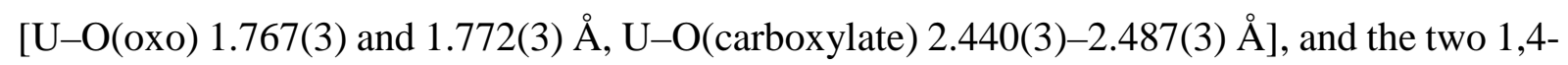
$\mathrm{PDA}^{2-}$ ligands (one of them centrosymmetric) are in the trans conformation (Figure 5). A 2D assembly parallel to $(10 \overline{\mathbf{1}})$ is formed, which has the $\left\{6^{3}\right\}$ point symbol and the hcb topology. The network is however extremely corrugated when viewed down [101], and 2-fold 2D + 2D $\rightarrow$ 2D parallel interpenetration ensues (Figure 5). The number of structures of uranyl complexes containing entangled nets has increased steadily in recent years (an inventory of those reported prior to 2017 has been given, ${ }^{26}$ and some others have since been reported ${ }^{32,54-}$ $\left.{ }^{56}\right)$. Interpenetration is enabled here by both the corrugation of the individual sheets and the rather large size of the hexanuclear rings $(\sim 20 \AA \times 10 \AA)$, although larger sizes have been reported, for example for hcb networks formed with terephthalate $(\sim 23 \AA \times 23 \AA$, 2-fold interpenetration $),{ }^{57} c, t$-1,4-cyclohexanedicarboxylate $(\sim 22 \AA \times 12 \AA$, 3-fold interpenetration $),{ }^{26}$ or 4,4'-biphenyldicarboxylate $(\sim 27 \AA \times 22 \AA, 2 \mathrm{D} \rightarrow 3 \mathrm{D}$ inclined polycatenation $) .{ }^{20}$ It is notable that, apart from the particular case of uranyl ion complexes, the hcb topology is frequently found in entangled nets. ${ }^{58}$ When viewed down the [010] axis, the interpenetrated nets form thick layers $(\sim 15 \AA)$ in which channels $(\sim 14 \AA \times 8 \AA)$ run along the [010] direction and contain the $\left[\mathrm{Cu}(\text { bipy })_{2}\right]^{+}$counterions, thus leaving no significant free space (KPI 0.67). Interpenetration results in separate nets contributing half each to the walls of the channels, and within each net the non-centrosymmetric ligand units alternate in chirality, making each net racemic in this regard. Within the channels, the $\left[\mathrm{Cu}(\text { bipy })_{2}\right]^{+}$cations, although just barely distorted from true tetrahedral geometry, are chiral but again there is an alternation of their chirality down the channels. The $\mathrm{H}_{2} \mathrm{NMe}_{2}{ }^{+}$cations, which have 2-fold rotation symmetry, are hydrogen bonded to

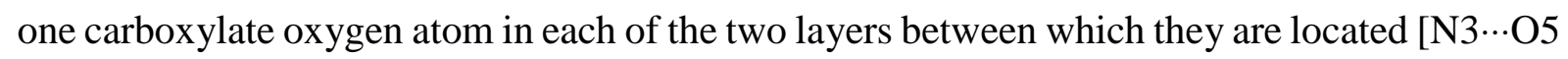
2.819(4) $\AA, \mathrm{N} 3-\mathrm{H} \cdots \mathrm{O} 5173^{\circ}$ ]. The $1,4-\mathrm{PDA}^{2-}$ and bipy ligands are possibly involved in two 
$\pi \cdots \pi$ interactions [centroid $\cdots$ centroid 4.026(4) and 4.100(3) $\AA$, dihedral angles $6.2(3)$ and 19.3(3) ${ }^{\circ}$, and one interlayer $\mathrm{CH} \cdots \pi$ contact between a methylene proton and a diacetate-bearing aromatic ring $\left[\mathrm{H} \cdots\right.$ centroid $2.92 \AA$, $\mathrm{C}-\mathrm{H} \cdots$ centroid $\left.131^{\circ}\right]$. As usual, $\mathrm{CH} \cdots \mathrm{O}$ hydrogen bonds involving protons from bipy and oxo or carboxylato acceptors are also found and clearly evident

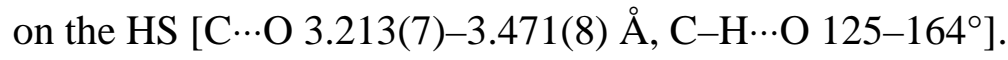

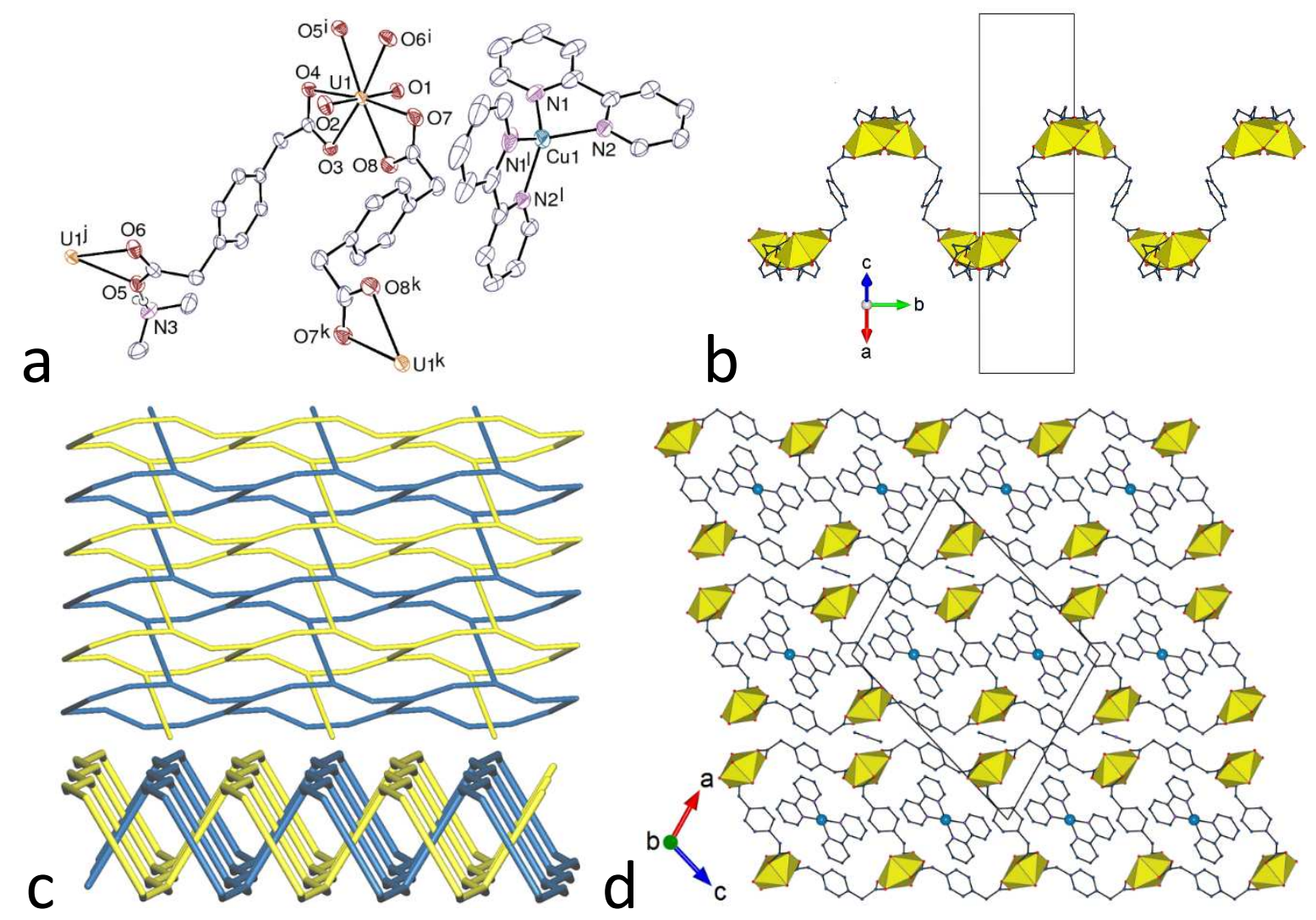

Figure 5. (a) View of compound 5. Displacement ellipsoids are drawn at the 50\% probability level. Symmetry codes: $\mathrm{i}=x-1 / 2,-y, z-1 / 2 ; \mathrm{j}=x+1 / 2,-y, z+1 / 2 ; \mathrm{k}=1-x, 1-y, 1-z ; \mathrm{l}=1 / 2-x, y, 1 / 2-z$. (b) View of one corrugated 2D network. (c) Nodal representations of the interpenetrated 2D networks. (d) View of the packing with layers viewed edge-on and copper atoms shown as blue spheres. Hydrogen atoms are omitted in all views.

Returning to the $\left[\mathrm{Zn}(\mathrm{phen})_{3}\right]^{2+}$ counterion, its association with $1,2-\mathrm{PDA}^{2-}$ gives the complex $\left[\mathrm{Zn}(\text { phen })_{3}\right]\left[\left(\mathrm{UO}_{2}\right)_{2}(1,2-\mathrm{PDA})_{3}\right] \cdot 7 \mathrm{H}_{2} \mathrm{O}(\mathbf{6})$, with the same stoichiometry as $\mathbf{3}$ and $\mathbf{4}$, but yet another geometrical arrangement. The two uranyl ions are tris-chelated [U-O(oxo) 
1.766(3)-1.780(3) ̊, U-O(carboxylate) 2.426(3)-2.509(3) $\AA$ ] and the three inequivalent 1,2$\mathrm{PDA}^{2-}$ ligands are in chiral trans conformations (Figure 6). The polymeric assembly formed is a 1D chain running along [100], which has a ladderlike shape, with two rows bridged by
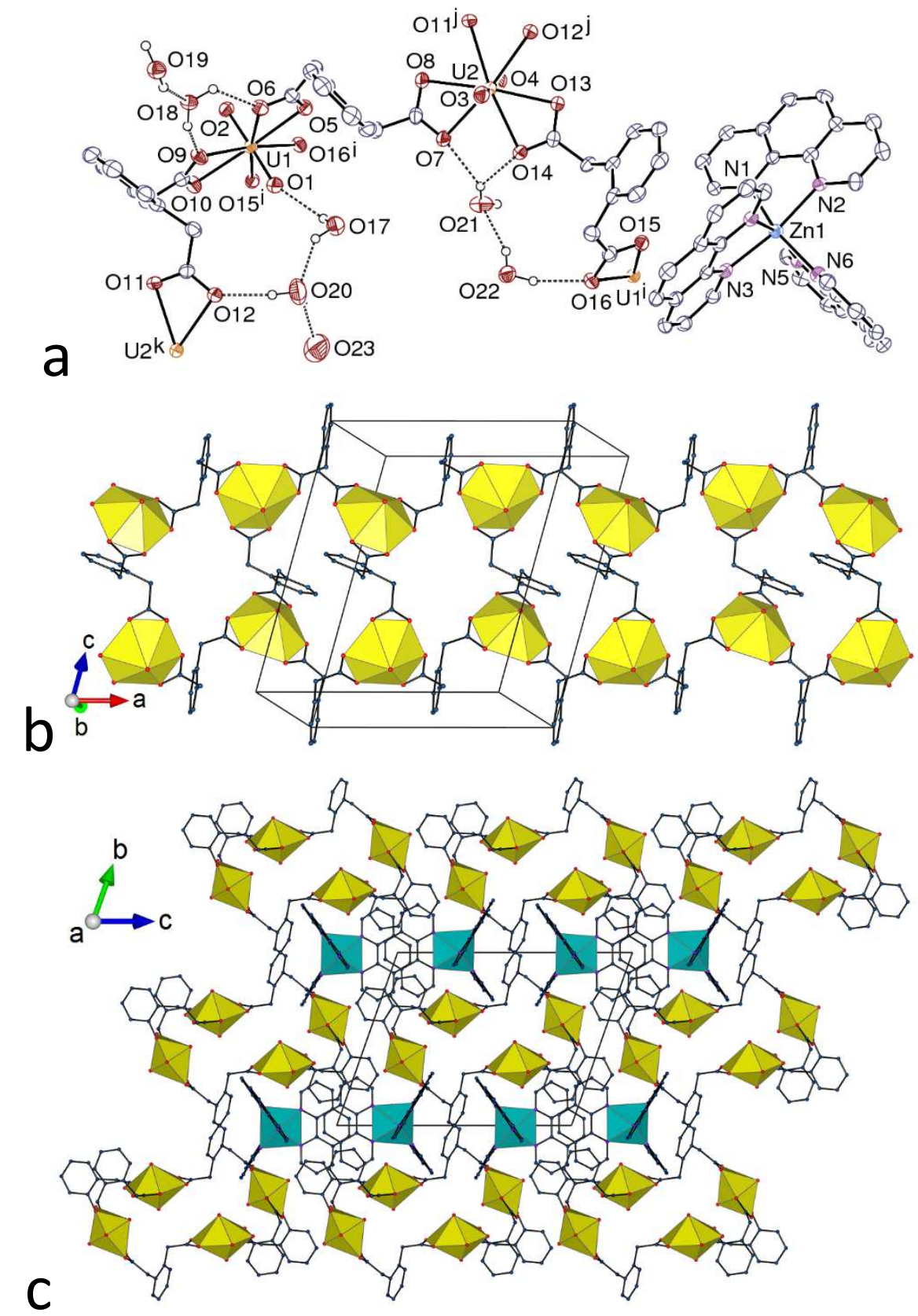

Figure 6. (a) View of compound 6. Displacement ellipsoids are drawn at the 50\% probability level. Carbon-bound hydrogen atoms are omitted and hydrogen bonds are shown as dashed lines. Symmetry codes: $\mathrm{i}=1-x, 1-y, 1-$ $z ; \mathrm{j}=x+1, y, z ; \mathrm{k}=x-1, y, z$. (b) View of the 1D ladderlike coordination polymer. (c) View of the packing with chains viewed end-on. Solvent molecules and hydrogen atoms are omitted in the last two views. 
central bridges, and the ligand chirality alternating along the bridges and within each of the rows. Viewed down the chain axis, the polymer is not flat, but has some extension along the direction perpendicular to the ribbons, so as to create a central channel (albeit an exceedingly small one), with all aromatic rings pointing outward. These chains are packed so as to leave room for channels directed along the same axis and containing the counterions (KPI 0.69). The phen ligand units penetrate the polymer chains slightly, with enantiomeric pairs of $\left[\mathrm{Zn}(\mathrm{phen})_{3}\right]^{2+}$ cations lying opposite one another in the approximately rectangular channels. The weak intermolecular interactions are of the usual types: $\pi \cdots \pi$ between $1,2-$ PDA $^{2-}$ and phen ligands [centroid $\cdots$ centroid 3.640(3)-4.266(3) $\AA$, dihedral angles $\left.0.3(2)-24.11(17)^{\circ}\right], \mathrm{CH} \cdots \pi$

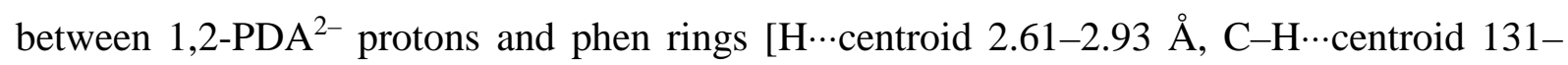
$168^{\circ}$ ], and $\mathrm{CH} \cdots \mathrm{O}$ between 1,2-PDA ${ }^{2-}$ and phen protons, and oxo, carboxylato and water oxygen atoms $\left[\mathrm{C} \cdots \mathrm{O} 3.124(5)-3.464(5) \AA, \mathrm{C}-\mathrm{H} \cdots \mathrm{O} 120-159^{\circ}\right]$. This compound is the most hydrated of the series and $\mathrm{OH} \cdots \mathrm{O}$ hydrogen bonds are numerous. The lattice water molecules are essentially located within the chain channel or in close proximity to the chain and form hydrogen bonds between themselves and with oxo and carboxylato groups [O $\cdots \mathrm{O}$ 2.697(7)3.304(4) $\AA, \mathrm{O}-\mathrm{H} \cdots \mathrm{O} 120-173^{\circ}$ ]. Curiously enough, these water molecules are readily lost when the crystals are taken out of the solution (see Experimental Section).

While 1,3-PDA ${ }^{2-}$ gives a $2 \mathrm{D}$ network with $\left[\mathrm{Zn}(\mathrm{phen})_{3}\right]^{2+}$ counterions in complex 3, replacement of phen by bipy gives the complex $\left[\mathrm{Zn}(\text { bipy })_{3}\right]\left[\left(\mathrm{UO}_{2}\right)_{2}(1,3-\mathrm{PDA})_{3}\right](7)$ which has the same stoichiometry, but crystallizes differently. The two tris-chelated uranyl cations [UO(oxo) 1.764(5)-1.771(6) A, U-O(carboxylate) 2.427(9)-2.518(10) $\mathrm{A}]$ are linked by three 1,3PDA $^{2-}$ ligands, two in the trans and one in the cis conformation (Figure 7) so as to form a $1 \mathrm{D}$ polymer running along [001], of topology analogous to that found in $\mathbf{6}$. However, the separation between the carboxylate groups, measured by the distance between the carboxylate carbon 

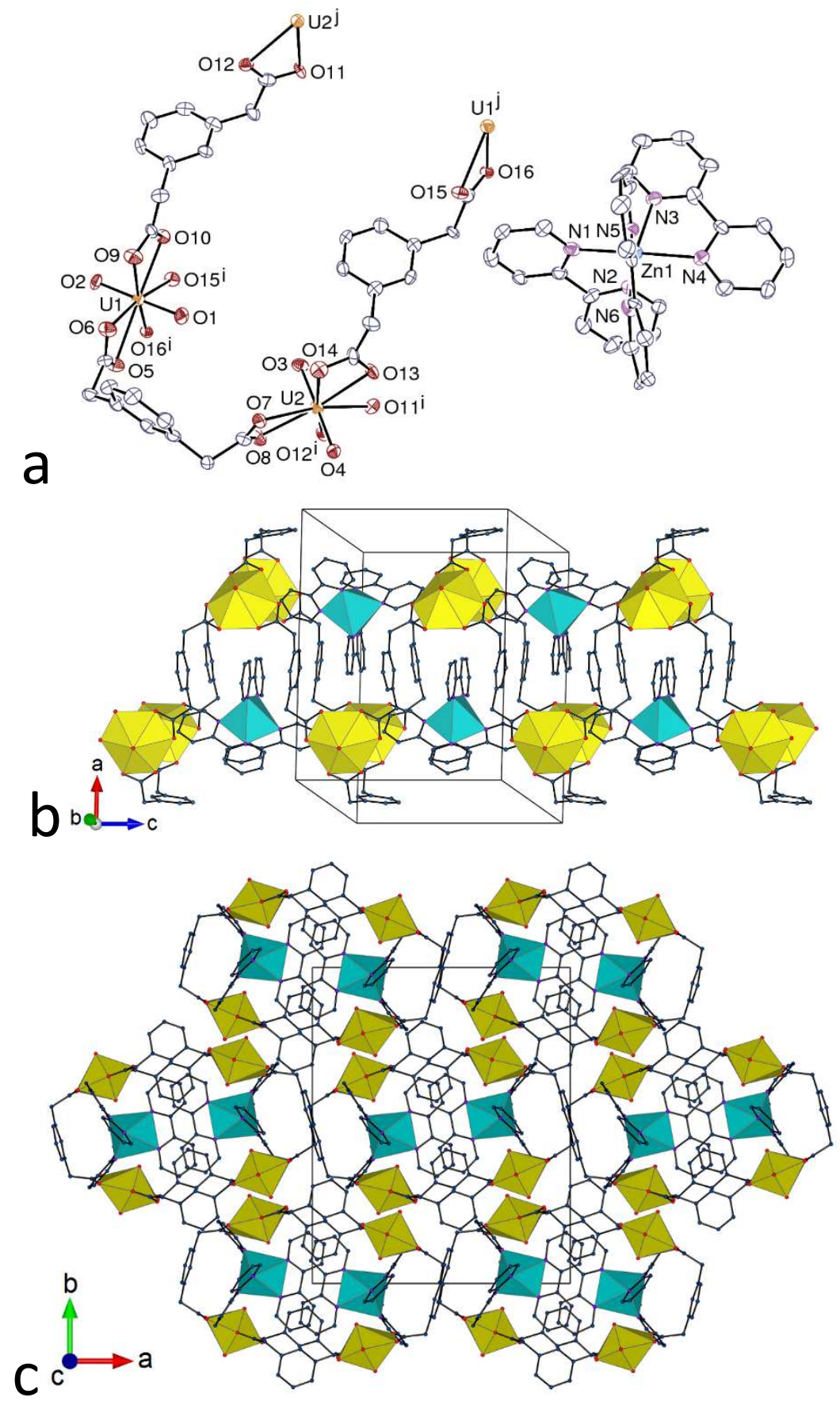

Figure 7. (a) View of compound 7. Displacement ellipsoids are drawn at the $50 \%$ probability level. Symmetry codes: $\mathrm{i}=1-x, 1-y, z-1 / 2 ; \mathrm{j}=1-x, 1-y, z+1 / 2$. (b) View of the nanotubular assembly with counterions included. (c) View of the packing down the nanotubule axis. Hydrogen atoms are omitted in all views.

atoms, is larger for 1,3-PDA ${ }^{2-}$ in 7 [6.062(13) $\AA$ for the cis form, 6.90(2) and 6.94(2) $\AA$ for the trans] than for $1,2-\mathrm{PDA}^{2-}$ in 6 [4.497(6), 4.032(6) and 4.488(6) $\AA$, all trans]. As a result, the polymer is more inflated and assumes a nanotubular shape of somewhat oblong section, with a 
size of $\sim 17 \AA \times 7 \AA$. Here, the tubular polymer units are chiral, as while the cross-bridging ligand units have an achiral conformation (mirror pseudo-symmetry), the row linkages are chiral and all have the same configuration in a given tube. These tubular chains have however no continuous wall preventing guest entry, but are largely open on their sides, with apertures of about $9 \AA$ along the chain axis. This enables the counterions to be included in the inner cavity while occupying these lateral open spaces, as shown in Figure 8, resulting in a compact packing

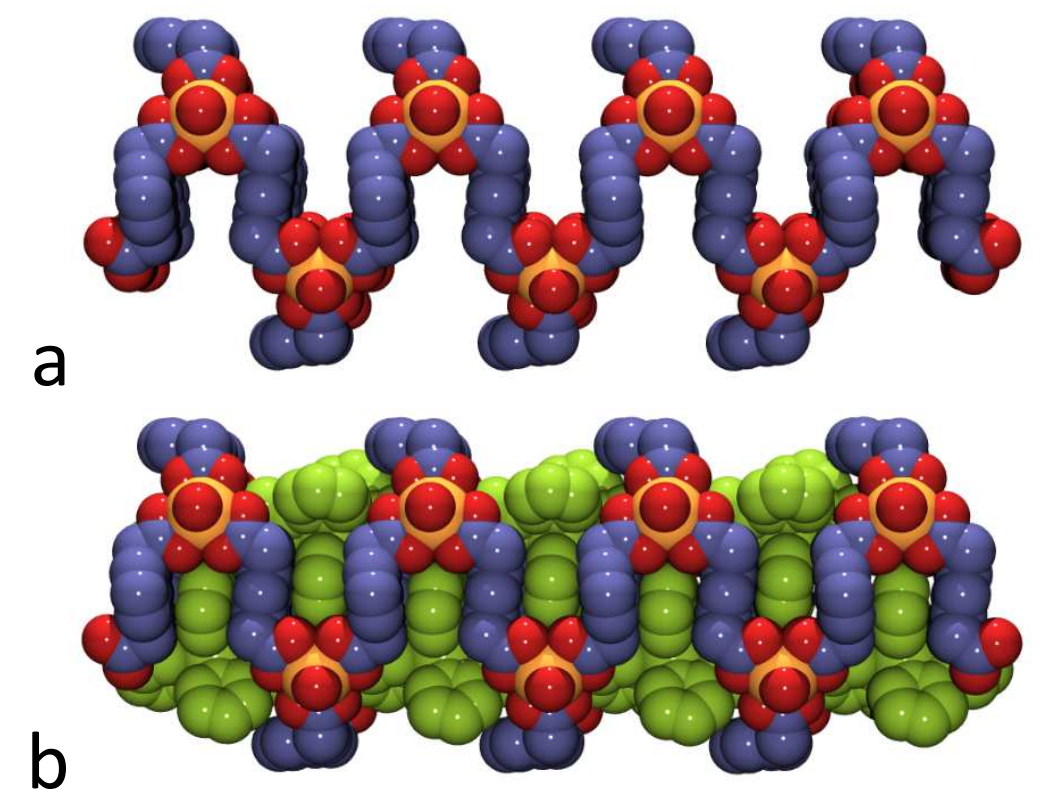

Figure 8. Spacefill representation of the nanotubular assembly in 7 without counterions (a) and with counterions included (b). Hydrogen atoms are omitted. Uranium, yellow; oxygen, red; carbon, blue; the whole counterions are shown in green.

(KPI 0.70). Some of the aromatic rings of the 1,3-PDA ${ }^{2-}$ ligands are pointing inward, which reduces the available inner space. Reflecting the chirality of the polymer tubules, the included cations are all of the same configuration, although this alternates from one sheet to another parallel to (010), making the lattice once again racemic. The counterions being far from one another, the only aromatic stacking arrays involve $1,3-\mathrm{PDA}^{2-}$ and bipy ligands [centroid $\cdots$ centroid 3.709(7)-3.807(7) $\AA$, dihedral angles 3.2(6)-20.2(6) ${ }^{\circ}$, and the $\mathrm{CH} \cdots \pi$ interactions involve only bipy rings as acceptors $[\mathrm{H} \cdots$ centroid $2.74-2.98 \AA$, $\mathrm{C}-\mathrm{H} \cdots$ centroid 
148-173 ${ }^{\circ}$, while the three $\mathrm{CH} \cdots \mathrm{O}$ hydrogen bonds are between bipy protons and carboxylato

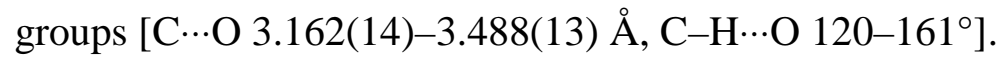

In an evolution analogous to that existing between complexes $\mathbf{3}$ and $\mathbf{7}$, replacement of the $\left[\mathrm{Ni}(\text { phen })_{3}\right]^{2+}$ counterions present in the $2 \mathrm{D}$ complex 4 by $\left[\mathrm{M}(\text { bipy })_{3}\right]^{2+}$ counterions $(\mathrm{M}=$ $\mathrm{Co}, \mathrm{Ni})$ in the case of $1,4-\mathrm{PDA}^{2-}$ gave the complexes $\left[\mathrm{Co}(\text { bipy })_{3}\right]\left[\left(\mathrm{UO}_{2}\right)_{2}(1,4-\mathrm{PDA})_{3}\right](\mathbf{8})$ and $\left[\mathrm{Ni}(\text { bipy })_{3}\right]\left[\left(\mathrm{UO}_{2}\right)_{2}(1,4-\mathrm{PDA})_{3}\right](\mathbf{9})$, which, as complex 7, display a nanotubular arrangement. These two complexes are isomorphous and crystallize in the orthorhombic space group $\mathrm{Cmcm}$ (similar isomorphous complexes were obtained with $\mathrm{Fe}^{\mathrm{II}}$ and $\mathrm{Zn}^{\mathrm{II}}$, but the crystal quality was lower in these cases). A significant difference from complex 7 is apparent in that one 1,4-PDA ${ }^{2-}$ ligand has mirror symmetry, and the tubes are thus not chiral. This may explain why the use of $\left[\mathrm{M}(\text { bipy })_{3}\right]^{2+}$ counterions containing both the $\Lambda$ and $\Delta$ forms results in disorder of the bipy groups, with the two forms mixed at each counterion site (see Experimental Section), the $3 \mathrm{~d}$ block metal cation being on a site of $m 2 m$ symmetry. This complication was eliminated through the use of the pure $\Lambda$ form of $\left[\mathrm{Ru}(\text { bipy })_{3}\right]^{2+}$, giving the complex $\left\{\Lambda-\left[\operatorname{Ru}(\text { bipy })_{3}\right]\right\}\left[\left(\mathrm{UO}_{2}\right)_{2}(1,4-\right.$ PDA) $)_{3}$ (10). This complex crystallizes in the orthorhombic Sohncke space group $C 222_{1}$, with unit cell parameters very close to those of $\mathbf{8}$ and $\mathbf{9}$ (the $a$ and $b$ axes being permuted), and is free of disorder. Views of complexes $\mathbf{8}$ and $\mathbf{9}$ are given in Figures S1 and S2 (Supporting Information) and complex $\mathbf{1 0}$ is represented in Figure 9. These three complexes display the same arrangement, notwithstanding the differences in symmetry, and the following description is based on complex $\mathbf{1 0}$ only. The connectivity is analogous to that found in $\mathbf{6}$ and $\mathbf{7}$ [U-O(oxo) 1.771(7) and 1.773(6) $\AA$, U-O(carboxylate) $2.446(8)-2.491(6) \AA]$ and the three ligands, all of which have twofold rotation symmetry, display the same mixture of cis and trans conformations as found in complex 7. The separation between the carboxylate groups in each ligand is however even larger than in 7, with C...C distances of 6.43(2) $\AA$ for the cis form, and 7.53(2) and 7.58(2) 

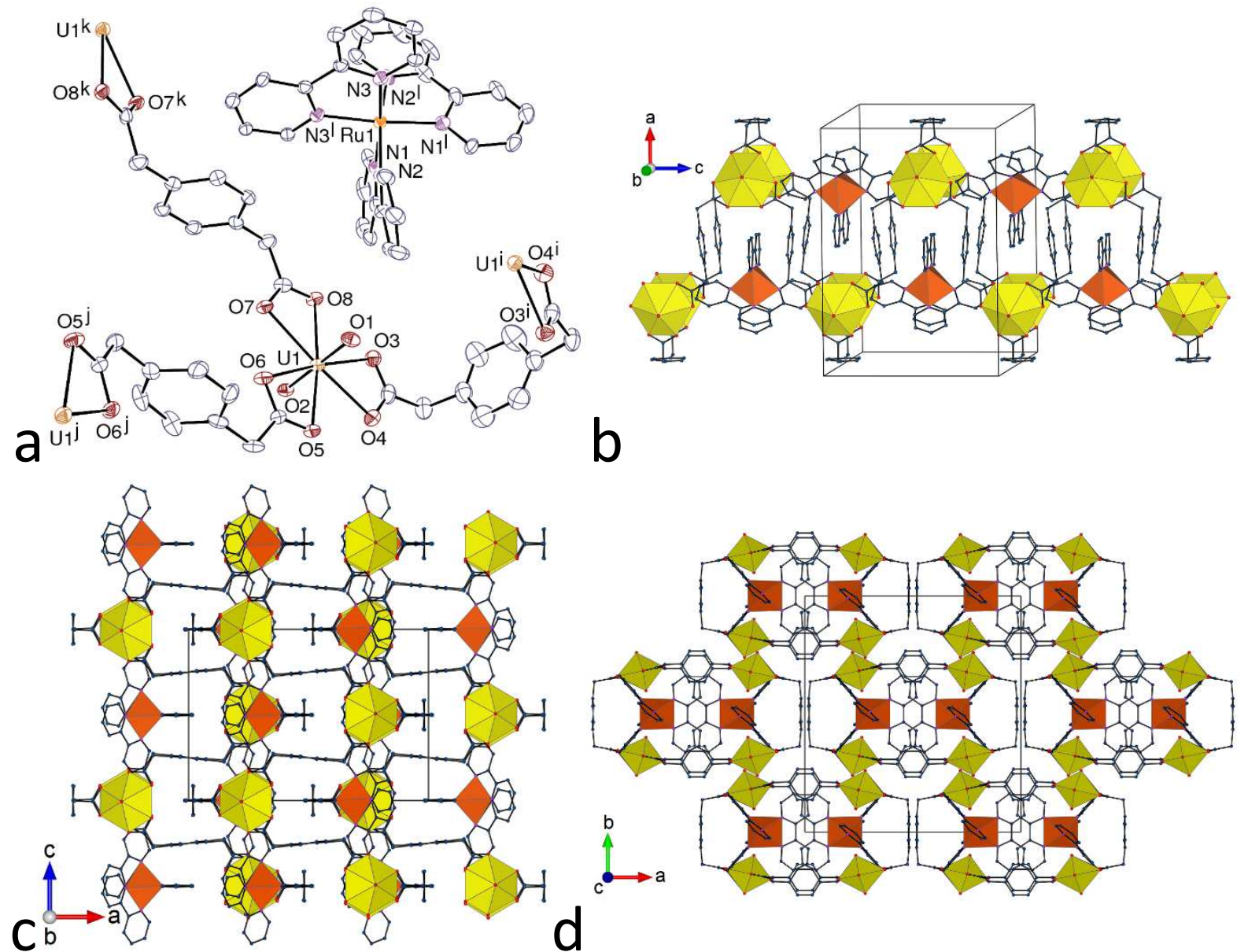

Figure 9. (a) View of compound 10. Displacement ellipsoids are drawn at the $30 \%$ probability level. Symmetry codes: $\mathrm{i}=x, 1-y, 1-z ; \mathrm{j}=1-x, y, 1 / 2-z ; \mathrm{k}=1-x, y, 3 / 2-z ; 1=x, 1-y, 2-z$. (b) View of the nanotubular assembly with counterions included. (c) Packing with the nanotubule axis vertical. (d) Packing viewed down the nanotubule axis. The uranium coordination polyhedra are colored yellow and those of ruthenium orange; hydrogen atoms are omitted in all views.

$\AA$ for the trans form. As a consequence, the nanotubular array is even more expanded than in 7, with a more regular oblong section of $\sim 19 \AA \times 7 \AA$ and gaps of $\sim 11 \AA$ along the chain length (the elongated section is reminiscent of that found in otherwise quite different uranyl diphosphonate nanotubules ${ }^{8-10}$, and also of the shape of the channels found in complex 5). The counterions fit snugly into the lateral apertures and occupy the central cavity (Figure 10). As in complex 7, parallel-displaced $\pi \cdots \pi$ stacking arrays are formed between the trans $1,4-\mathrm{PDA}^{2-}$ ligands and the bipy molecules most imbedded in the cavity [centroid $\cdots$ centroid 4.106(6) and 
4.379(7) $\AA$, dihedral angles 4.0(5) and 7.5(6) ${ }^{\circ}$; there is no $\mathrm{CH} \cdots \pi$ interaction, but three $\mathrm{CH} \cdots \mathrm{O}$ hydrogen bonds link protons of both ligands to oxo and carboxylato groups [C… 3.240(14)$\left.3.419(15) \AA, \mathrm{C}-\mathrm{H} \cdots \mathrm{O} 147-151^{\circ}\right]$. The packing is compact, with no available free space (KPI $0.67)$.

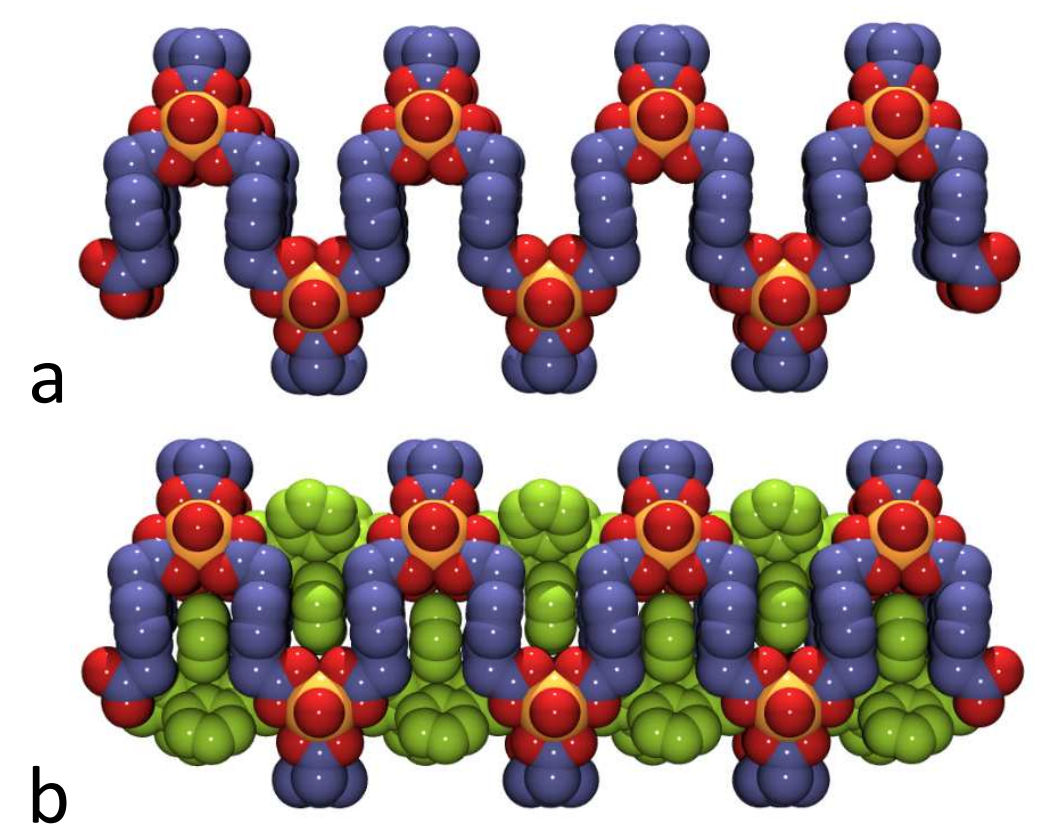

Figure 10. Spacefill representation of the nanotubular assembly in $\mathbf{1 0}$ without counterions (a) and with counterions included (b). Hydrogen atoms are omitted. Uranium, yellow; oxygen, red; carbon, blue; the whole counterions are shown in green.

The five complexes $\mathbf{6}-\mathbf{1 0}$ contain anionic uranyl coordination polymers having the same connectivity, but the difference in ligand conformation (all trans in $\mathbf{6}$, mixtures of cis and trans in all the others, and variations in the degree of twisting) and the varying separation between carboxylate groups in the series of positional diacetate isomers result in an evolution, represented in Figure 11, from a ladderlike assembly in $\mathbf{6}$ to a nanotubular geometry with a small inner channel in 7, and finally to a more typical nanotubular arrangement in $\mathbf{8}-\mathbf{1 0}$, with a significant cavity, albeit very elongated and not cylindrical as more usual in nanotubes. The presence of one ligand in the cis conformation in 7-10 plays an essential role here in providing 

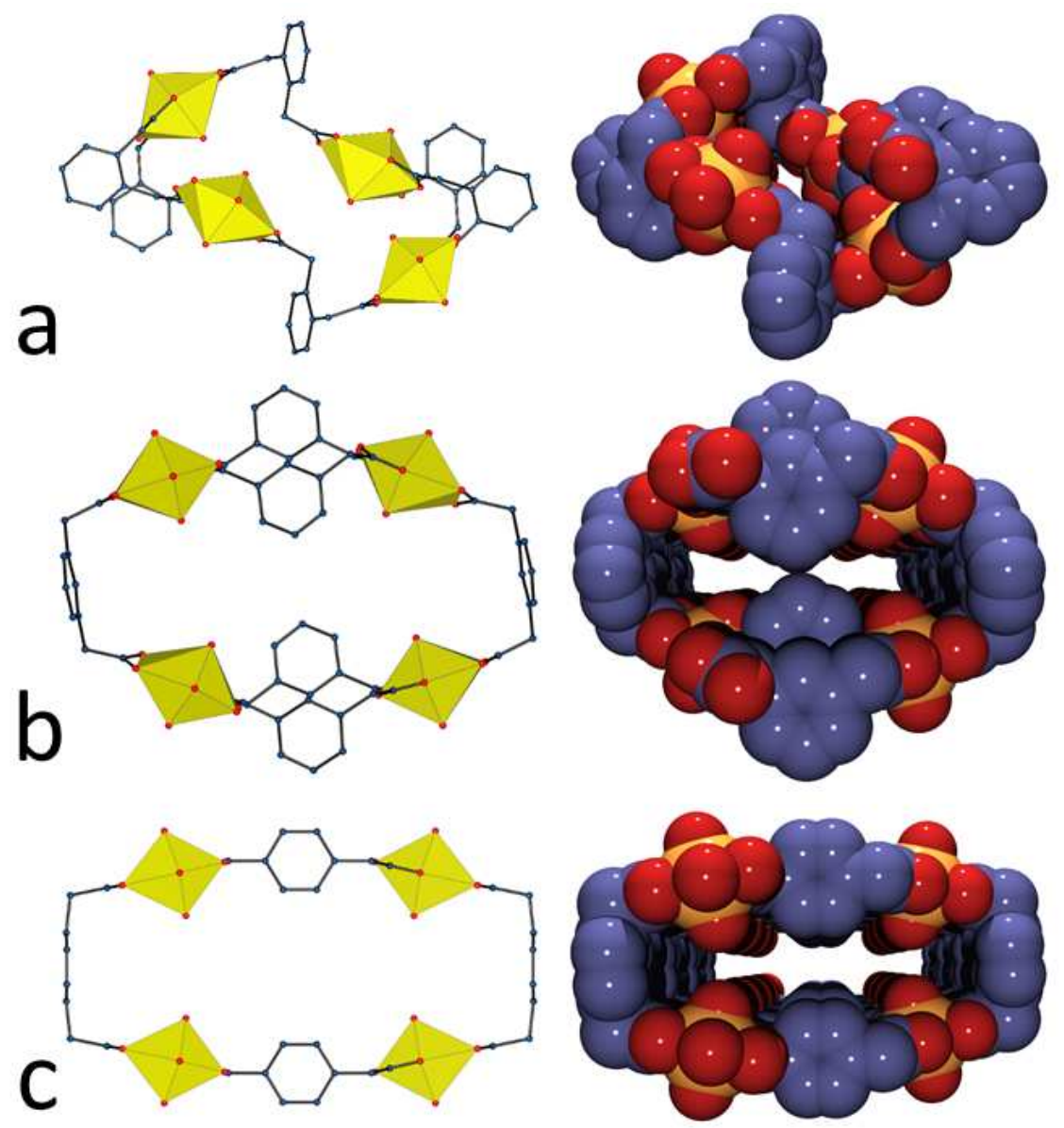

Figure 11. Polyhedral (left) and spacefill (right) representations of the 1D ladderlike and nanotubular assemblies in compounds $\mathbf{6}$ (a), 7 (b), and $\mathbf{1 0}$ (c) viewed down the chain axis. Uranium, yellow; oxygen, red; carbon, blue.

a convergent part, while the trans ligands span the larger sides. Considering the uranium 3-fold nodes, the point symbol is $\left\{4^{2} .6\right\}$ in all these complexes, corresponding to a succession of square rings sharing two nodes and tilted with respect to one another. Different topologies have been found in previous uranyl carboxylate nanotubules, which are represented in Figure 12. The simplest cases apart from the present ones are those of nanotubules based on honeycombtype connectivity, and thus reminiscent of carbon nanotubes, such as are found in complexes with tricarballylate, ${ }^{19}$ and all-cis-1,3,5-cyclohexanetricarboxylate, ${ }^{18}$ the diameters of the tubules in these two cases depending on the curvature of the rings. In the case of phthalate, ${ }^{14}$ both uranium and ligand are 4-fold nodes and the point symbol is $\left\{4^{4} \cdot 6^{2}\right\}$, the nanotubule being cylindrical, and with no gaps in its walls. The case of Kemp's tricarboxylate is more 
complicated due to the presence of decorating nickel(II) cations, but in this case also, the nanotubules are cylindrical with no lateral gaps. ${ }^{17}$ Iminodiacetate is a peculiar case since the nanotubules are formed from the superposition of highly corrugated hexagonal rings. ${ }^{15}$ Obviously, the present nanotubules are the simplest among the polymeric ones and they are also those most open to the outside environment due to the lateral gaps, from which their occupation by the bulky counterions ensues. Due to their flattened shape and lateral porosity, these assemblies would more properly be called 'tubelike', although 'tubular' is most often used here for simplicity. Moreover, 'nanotubule' may be a more proper word for all these uranyl-based species, so as to distinguish them from free-standing nanotubes. ${ }^{18}$
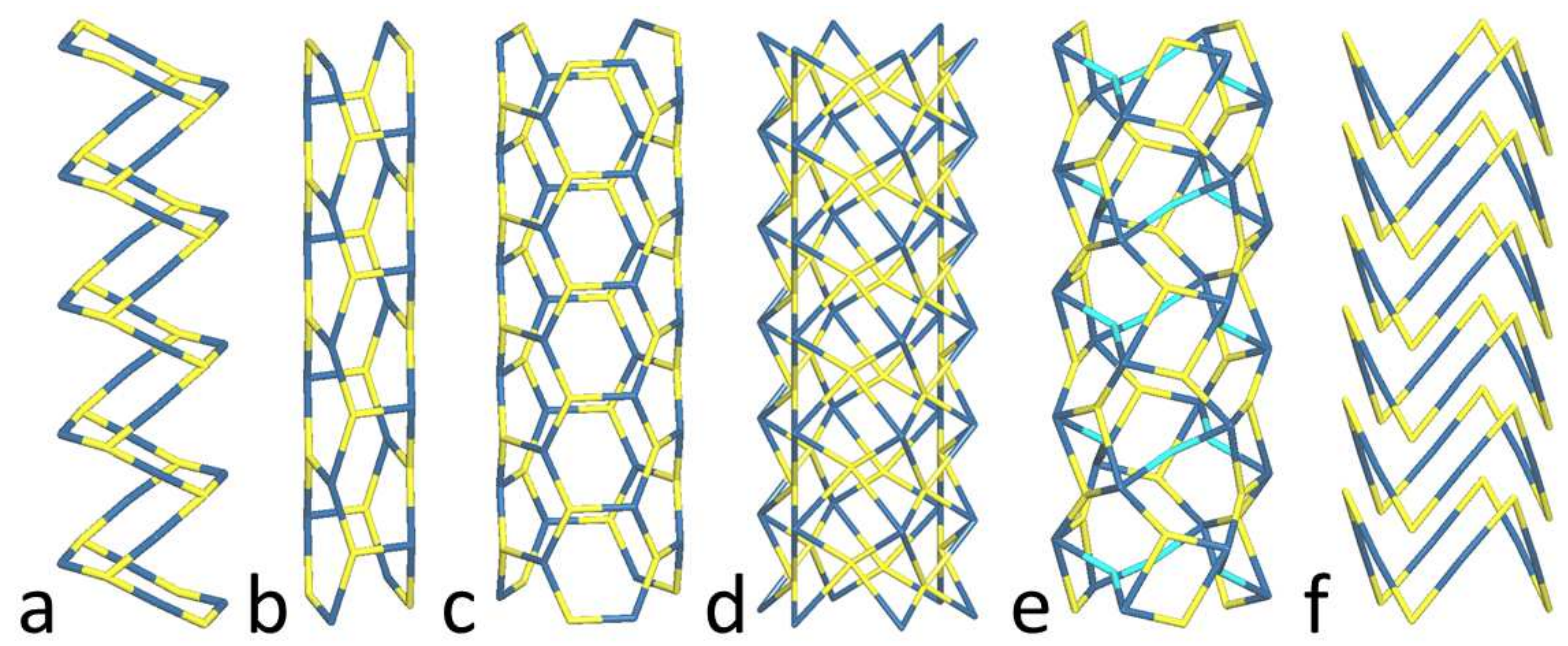

Figure 12. Nodal representations of uranyl carboxylate nanotubules with 1,3- and 1,4-phenylenediacetates (a), tricarballylate $^{19}$ (b), all-cis-1,3,5-cyclohexanetricarboxylate ${ }^{18}$ (c), phthalate $^{14}(\mathrm{~d}), \operatorname{Kemp}^{\text {'s }}$ tricarboxylate $^{17}$ (e), and iminodiacetate $^{15}$ (f). Uranium, yellow; nickel, light blue; polycarboxylate ligands, dark blue.

An interesting point is the effect of $\left[\mathrm{M}(\mathrm{L})_{n}\right]^{q+}$ cations as structure-inducing species in the present series. The $\left[\mathrm{M}(\mathrm{L})_{2}\right]^{q+}$ cations give only 1D structures when they are part of the polymeric species itself, as in complexes $\mathbf{1}$ and $\mathbf{2}$, or a 2D network when they are separated as in 5. The nanotubular arrays could only be obtained with the somewhat spherical $\left[\mathrm{M}(\mathrm{L})_{3}\right]^{2+}$ cations. The different sizes of bipy and phen seem to play a role here since, in the case of 1,2- 
$\mathrm{PDA}^{2-}$, the larger $\left[\mathrm{Zn}(\mathrm{phen})_{3}\right]^{2+}$ cation gives the ladderlike, proto-tubular assembly found in $\mathbf{6}$, while, for $1,3-$ and $1,4-\mathrm{PDA}^{2-},\left[\mathrm{M}(\text { phen })_{3}\right]^{2+}$ favors $2 \mathrm{D}$ networks and $\left[\mathrm{M}(\text { bipy })_{3}\right]^{2+}$ yields nanotubular species. Unfortunately, no complex with $\left[\mathrm{M}(\text { bipy })_{3}\right]^{2+}$ counterions could be isolated in the case of 1,2-PDA ${ }^{2-}$, reaction with bipy and nickel(II) or zinc(II), for example, giving a homometallic uranyl complex with bipy as a coligand which will be reported in due time. It appears that the $\left[\mathrm{M}(\text { bipy })_{3}\right]^{2+}$ cation is perfectly suited for inclusion in the cavities of the nanotubules formed with $1,3-$ and $1,4-\mathrm{PDA}^{2-}$, whereas $\left[\mathrm{M}(\mathrm{phen})_{3}\right]^{2+}$ is most probably too bulky for that. An analogous influence of replacement of bipy by phen in $\left[\mathrm{M}(\mathrm{L})_{3}\right]^{2+}$ counterions was previously found in the series of uranyl complexes with long-chain aliphatic $\alpha, \omega$ dicarboxylates, [OOC- $\left.\left(\mathrm{CH}_{2}\right)_{n-2}-\mathrm{COO}\right]^{2-}\left(\mathrm{Cn}^{2-}\right)$, with bipy and phen promoting the formation of triple-stranded helicates with $\mathrm{C} 9^{2-}$ and $\mathrm{C} 12^{2-}$, respectively, ${ }^{21}$ the reverse associations giving $2 \mathrm{D}$ networks. ${ }^{46}$ The necessity to find the perfect size match between anionic and cationic parts to favor the formation of closed species subtends the strategy adopted here, consisting in screening both dicarboxylate ligand isomers and counterions.

Luminescence properties. Emission spectra under excitation at $420 \mathrm{~nm}$ were recorded for all complexes in the solid state, except for $\mathbf{4}$ and $\mathbf{1 0}$, for which a sufficient quantity of pure sample could not be isolated (however, an attempt at measurement of the spectrum of $\mathbf{1 0}$ on an impure sample only showed emission of $\left.\left[\operatorname{Ru}(\text { bipy })_{3}\right]^{2+}\right)$. Although uranium is in a tris-chelated hexagonal bipyramidal environment in all cases, there are some variations of the spectra in the series. An interesting point is that the four complexes containing $\mathrm{Zn}^{\mathrm{II}}$ cations, whatever their dimensionality, possess perfectly superimposable spectra (after normalisation), shown in Figure 13. These spectra display the usual fine structure associated with the vibronic progression corresponding to the $S_{11} \rightarrow S_{00}$ and $S_{10} \rightarrow S_{0 v}(v=0-4)$ electronic transitions. ${ }^{59}$ The main maxima in the spectra of $\mathbf{1}, \mathbf{3}, \mathbf{6}$ and $\mathbf{7}$ are at $463,481,501,523,546$ and $572 \mathrm{~nm}( \pm 1 \mathrm{~nm})$, these 
values being typical of tris-chelated uranyl carboxylate complexes. ${ }^{26}$ The spectrum of the $\mathrm{Mn}^{\mathrm{II}}$ containing complex 2, also shown in Figure 13, is redshifted with respect to the previous ones by only $1-2 \mathrm{~nm}$. In contrast, the spectrum of the $\mathrm{Ni}^{\mathrm{II}}$-containing complex $\mathbf{9}$ is also well-resolved but it is redshifted by about $12 \mathrm{~nm}$ with respect to the previous ones, giving values for the maxima positions significantly larger than those usual for $\mathrm{O}_{6}$ uranyl equatorial environments. Although badly resolved, the spectrum of the $\mathrm{Co}^{\mathrm{II}}$-containing complex $\mathbf{8}$ displays maxima positions similar to those measured for $\mathbf{9}$, and the very weak maxima found for the $\mathrm{Cu}^{\mathrm{I}}-$ containing complex 5 are also located in the same range (Figure 14). Uranyl luminescence in $\mathbf{5}$, and in a lesser measure in $\mathbf{8}$ also, is largely quenched. For comparison, the emission spectrum of uranyl nitrate hexahydrate is shown in Figure 14. This spectrum displays four main peaks at $486,508,532$, and $557 \mathrm{~nm}$, which are redshifted by about $5-11 \mathrm{~nm}$ with respect to those for complexes 1-3, 6 and 7, and blueshifted by about $5 \mathrm{~nm}$ with respect to those for complexes 8 and 9.

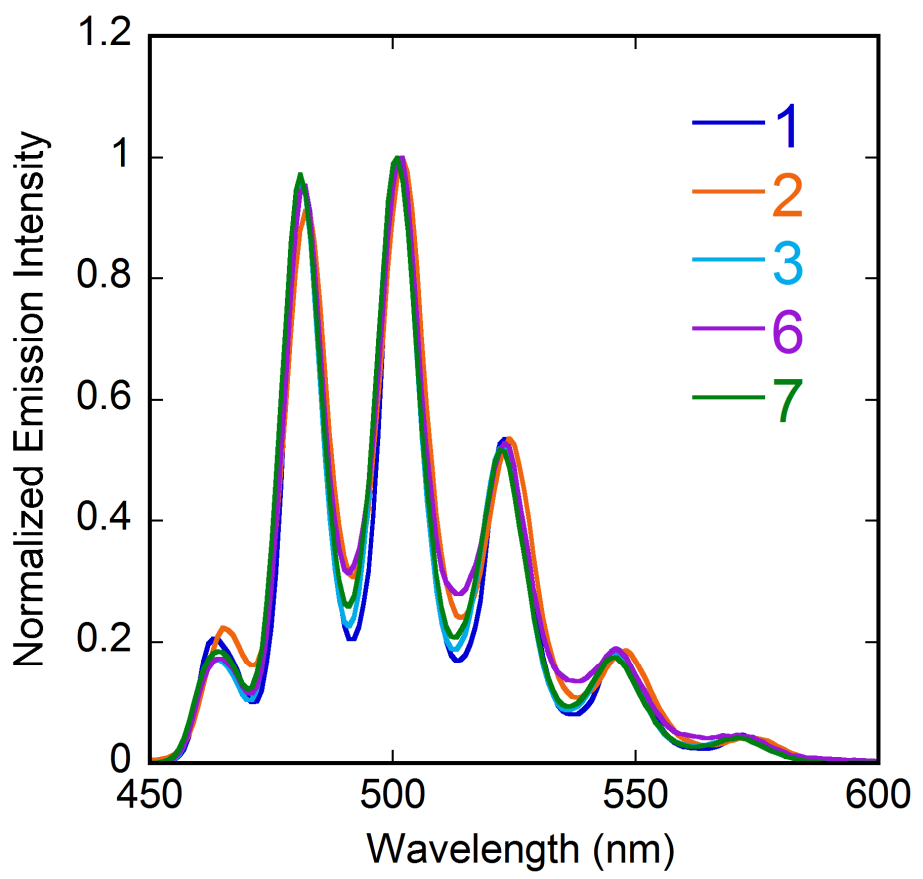

Figure 13. Emission spectra of compounds 1-3, 6 and 7 in the solid state at room temperature, under excitation at a wavelength of $420 \mathrm{~nm}$. 
Solid-state photoluminescence quantum yields (PLQYs) in this series of complexes are generally low, being $1 \%$ for $\mathbf{2 , 8}$ and $\mathbf{9}$, and $3 \%$ for $\mathbf{3 , 6}$ and $\mathbf{7}$, but a larger value of $11 \%$ was obtained for 1 . The latter value is comparable to those in the range of $6-13 \%$ recently measured in other uranyl carboxylate complexes, ${ }^{27,30-32}$ but smaller than the values of $23 \%$ found in a complex with $(1 R, 3 S)-(+)$-camphorate, $24 \%$ in uranyl nitrate hexahydrate, $42 \%$ in a dipicolinate complex, ${ }^{33} 49 \%$ in a succinate complex, ${ }^{60}$ and $58 \%$ in a benzene-1,3,5-tricarboxylate complex. ${ }^{61}$

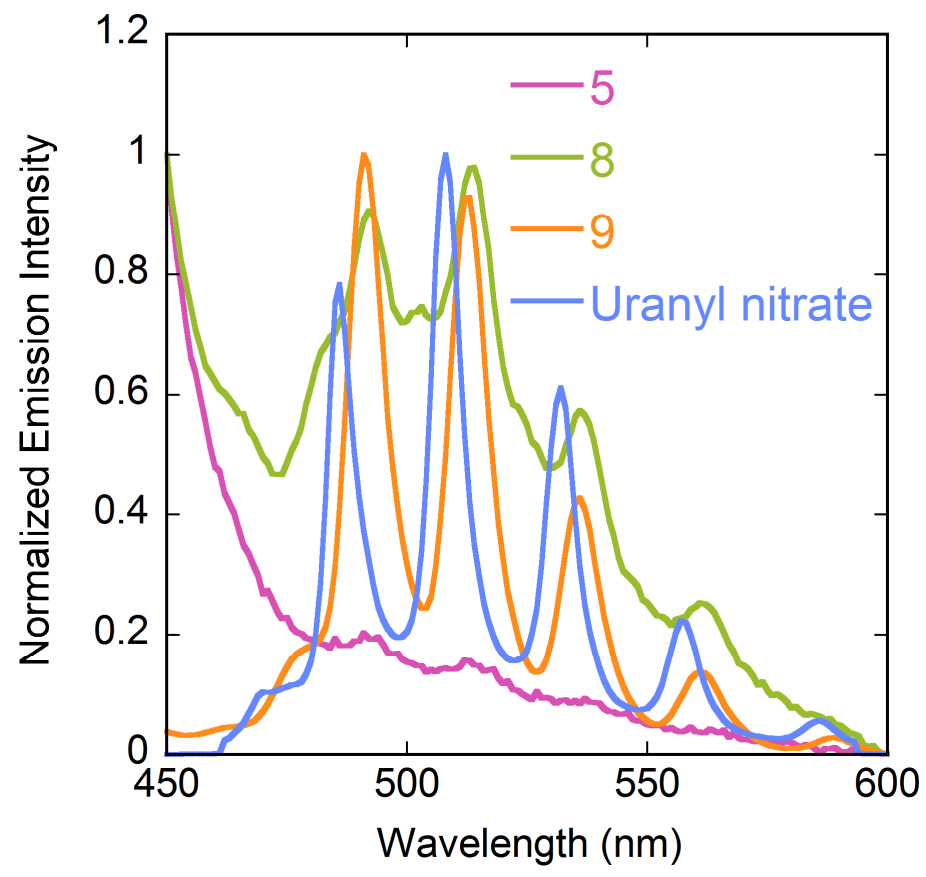

Figure 14. Emission spectra of compounds 5, 8, 9, and uranyl nitrate hexahydrate in the solid state at room temperature, under excitation at a wavelength of $420 \mathrm{~nm}$.

\section{CONCLUSIONS}

We have reported the synthesis, crystal structure and, in most cases, emission spectrum of ten uranyl ion complexes with the three positional isomers of phenylenediacetate, in the presence of bipy- or phen-coordinated metal cations as counterions. These diacetate ligands were chosen for their flexibility which enables them to act as either convergent or divergent linkers, with an adjustable separation between the coordination sites depending on the isomer considered. The 
different isomer/counterion combinations were screened in the hope of finding the suitable associations favoring the formation of closed species. Indeed, it appeared that the two isomers with the largest separation between the carboxylate groups, 1,3- and 1,4-PDA ${ }^{2-}$, gave polymeric, tubelike assemblies in the presence of $\left[\mathrm{M}(\text { bipy })_{3}\right]^{2+}$ counterions, while the third isomer, 1,2-PDA ${ }^{2-}$, yielded a slightly inflated ribbon with the same topology, which can be viewed as a proto-tubular species, in the presence of $\left[\mathrm{Zn}(\mathrm{phen})_{3}\right]^{2+}$. The other diacetate/counterion combinations which have given crystalline materials yielded more usual $1 \mathrm{D}$ or 2D assemblies, one of the latter providing another example of parallel 2D interpenetration. The tube-like assemblies have an original geometry, with an oblong section and large gaps in the walls, enabling the inclusion of the bulky counterions in the cavity. In all the present cases, there is some degree of interaction between various contributions to the chirality of the lattices, principally those concerning the ligand conformations and the configuration of the transition metal counterions. In no case, however, did the use of racemic reactants result in conglomerates where any given crystal was chiral through spontaneous resolution, so that the use of resolved, inversion-stable ligands such as $(1 R, 3 S)-(+)$-camphorate remains the simplest method ${ }^{33}$ for obtaining chiral uranyl ion coordination frameworks.

\section{ASSOCIATED CONTENT}

\section{Accession Codes}

CCDC 1904162-1904171 contain the supplementary crystallographic data for this paper. These data can be obtained free of charge via www.ccdc.cam.ac.uk/data_request/cif, or by emailing data_request@ccdc.cam.ac.uk, or by contacting The Cambridge Crystallographic Data Centre, 12 Union Road, Cambridge CB2 1EZ, UK; fax: +44 1223336033. 


\section{Supporting Information}

Figures S1 and S2. This information is available free of charge via the Internet at http://pubs.acs.org/.

\section{AUTHOR INFORMATION}

\section{Corresponding Authors}

*E-mail: pierre.thuery@cea.fr. (P.T.)

*E-mail: harrowfield@unistra.fr. (J.H.)

\section{ORCID}

Pierre Thuéry: 0000-0003-1683-570X

Youssef Atoini: 0000-0003-4851-3713

Jack Harrowfield: 0000-0003-4005-740X

Notes

The authors declare no competing financial interest.

\section{REFERENCES}

1. Wang, K. X.; Chen, J. S. Extended Structures and Physicochemical Properties of UranylOrganic Compounds. Acc. Chem. Res. 2011, 44, 531-540.

2. Andrews, M. B.; Cahill, C. L. Uranyl Bearing Hybrid Materials: Synthesis, Speciation, and Solid-State Structures. Chem. Rev. 2013, 113, 1121-1136.

3. Loiseau, T.; Mihalcea, I.; Henry, N.; Volkringer, C. The Crystal Chemistry of Uranium Carboxylates. Coord. Chem. Rev. 2014, 266-267, 69-109.

4. Su, J.; Chen, J. S. MOFs of Uranium and the Actinides. Struct. Bond. 2015, 163, 265-296. 
5. Thuéry, P.; Harrowfield, J. Recent Advances in Structural Studies of Heterometallic UranylContaining Coordination Polymers and Polynuclear Closed Species. Dalton Trans. 2017, 46, $13660-13667$.

6. Hickam, S.; Burns, P. C. Oxo Clusters of $5 f$ Elements. Struct. Bonding (Berlin, Ger.) 2017, 173, $121-154$.

7. Gagnon, K. J.; Perry, H. P.; Clearfield, A. Conventional and Unconventional Metal-Organic Frameworks Based on Phosphonate Ligands: MOFs and UMOFs. Chem. Rev. 2012, 112, 1034 1054.

8. Adelani, P. O.; Albrecht-Schmitt, T. E. Differential Ion Exchange in Elliptical Uranyl Diphosphonate Nanotubules. Angew. Chem. Int. Ed. 2010, 49, 8909-8911.

9. Adelani, P. O.; Albrecht-Schmitt, T. E. Metal-Controlled Assembly of Uranyl Diphosphonates toward the Design of Functional Uranyl Nanotubules. Inorg. Chem. 2011, 50, 12184-12191.

10. Adelani, P. O.; Cook, N. D.; Babo, J. M.; Burns, P. C. Incorporation of $\mathrm{Cu}^{2+}$ Ions into Nanotubular Uranyl Diphosphonates. Inorg. Chem. 2014, 53, 4169-4176.

11. Krivovichev, S. V.; Kahlenberg, V.; Tananaev, I. G.; Kaindl, R.; Mersdorf, E.; Myasoedov, B. F. Highly Porous Uranyl Selenate Nanotubules. J. Am. Chem. Soc. 2005, 127, 1072-1073.

12. Krivovichev, S. V.; Kahlenberg, V.; Kaindl, R.; Mersdorf, E.; Tananaev, I. G.; Myasoedov, B. F. Nanoscale Tubules in Uranyl Selenates. Angew. Chem. Int. Ed. 2005, 44, 1134-1136.

13. Alekseev, E. V.; Krivovichev, S. V.; Depmeier, W. A Crown Ether as Template for Microporous and Nanostructured Uranium Compounds. Angew. Chem. Int. Ed. 2008, 47, 549551.

14. Mihalcea, I.; Henry, N.; Loiseau, T. Revisiting the Uranyl-Phthalate System: Isolation and Crystal Structures of Two Types of Uranyl-Organic Frameworks (UOF). Cryst. Growth Des. 2011, 11, 1940-1947. 
15. Unruh, D. K.; Gojdas, K.; Libo, A.; Forbes, T. Z. Development of Metal-Organic Nanotubes Exhibiting Low-Temperature, Reversible Exchange of Confined "Ice Channels". J. Am. Chem. Soc. 2013, 135, 7398-7401.

16. Jayasinghe, A. S.; Unruh, D. K.; Kral, A.; Libo, A.; Forbes, T. Z. Structural Features in Metal-Organic Nanotube Crystals That Influence Stability and Solvent Uptake. Cryst. Growth Des. 2015, 15, 4062-4070.

17. Thuéry, P. A Highly Adjustable Coordination System: Nanotubular and Molecular Cage Species in Uranyl Ion Complexes with Kemp's Triacid. Cryst. Growth Des. 2014, 14, 901-904.

18. Thuéry, P.; Harrowfield, J. Uranyl Ion Complexes with all-cis-1,3,5Cyclohexanetricarboxylate: Unexpected Framework and Nanotubular Assemblies. Cryst. Growth Des. 2014, 14, 4214-4225.

19. Thuéry, P.; Harrowfield, J. Variations on the Honeycomb Topology: From Triangular- and Square-Grooved Networks to Tubular Assemblies in Uranyl Tricarballylate Complexes. Cryst. Growth Des. 2017, 17, 963-966.

20. Thuéry, P.; Harrowfield, J. Structural Variations in the Uranyl/4,4'-Biphenyldicarboxylate System. Rare Examples of 2D $\rightarrow$ 3D Polycatenated Uranyl-Organic Networks. Inorg. Chem. 2015, 54, 8093-8102.

21. Thuéry, P.; Harrowfield, J. A New Form of Triple-Stranded Helicate Found in Uranyl Complexes of Aliphatic $\alpha, \omega$-Dicarboxylates. Inorg. Chem. 2015, 54, 10539-10541.

22. Thuéry, P. From Helicates to Borromean Links: Chain Length Effect in Uranyl Ion Complexes of Aliphatic $\alpha, \omega$-Dicarboxylates. Cryst. Growth Des. 2016, 16, 546-549.

23. Thuéry, P.; Harrowfield, J. Counter-Ion Control of Structure in Uranyl Ion Complexes with 2,5-Thiophenedicarboxylate. CrystEngComm 2016, 18, 1550-1562.

24. Thuéry, P.; Rivière, E.; Harrowfield, J. Counterion-Induced Variations in the Dimensionality and Topology of Uranyl Pimelate Complexes. Cryst. Growth Des. 2016, 16, 2826-2835. 
25. Thuéry, P.; Harrowfield, J. Complexes of Uranyl Ions with Aromatic Di- and Tetracarboxylates Involving $\left[\mathrm{Ni}(\text { bipy })_{n}\right]^{2+}(n=2,3)$ Counterions. Eur. J. Inorg. Chem. 2017, $5451-5460$.

26. Thuéry, P.; Harrowfield, J. Structural Consequences of 1,4-Cyclohexanedicarboxylate Cis/Trans Isomerism in Uranyl Ion Complexes: From Molecular Species to 2D and 3D Entangled Nets. Inorg. Chem. 2017, 56, 13464-13481.

27. Thuéry, P.; Atoini, Y.; Harrowfield, J. Uranyl-Organic Coordination Polymers with trans1,2-, trans-1,4-, and cis-1,4-Cyclohexanedicarboxylates: Effects of Bulky $\mathrm{PPh}_{4}{ }^{+}$and $\mathrm{PPh}_{3} \mathrm{Me}^{+}$ Counterions. Cryst. Growth Des. 2018, 18, 2609-2619.

28. Thuéry, P.; Atoini, Y.; Harrowfield, J. Crown Ethers and Their Alkali Metal Ion Complexes as Assembler Groups in Uranyl-Organic Coordination Polymers with cis-1,3-, cis-1,2-, and trans-1,2-Cyclohexanedicarboxylates. Cryst. Growth Des. 2018, 18, 3167-3177.

29. Thuéry, P.; Harrowfield, J. $[\mathrm{Ni}(\text { cyclam })]^{2+}$ and $\left[\mathrm{Ni}\left(R, S-\mathrm{Me}_{6} \text { cyclam }\right)\right]^{2+}$ as Linkers or Counterions In Uranyl-Organic Species with cis- and trans-1,2-Cyclohexanedicarboxylate Ligands. Cryst. Growth Des. 2018, 18, 5512-5520.

30. Thuéry, P.; Atoini, Y.; Harrowfield, J. Counterion-Controlled Formation of an Octanuclear Uranyl Cage with cis-1,2-Cyclohexanedicarboxylate Ligands. Inorg. Chem. 2018, 57, 62836288.

31. Thuéry, P.; Atoini, Y.; Harrowfield, J. Closed Uranyl-Dicarboxylate Oligomers: A Tetranuclear Metallatricycle with Uranyl Bridgeheads and 1,3-Adamantanediacetate Linkers. Inorg. Chem. 2018, 57, 7932-7939.

32. Thuéry, P.; Atoini, Y.; Harrowfield, J. Structure-Directing Effects of Counterions in Uranyl Ion Complexes with Long-Chain Aliphatic $\alpha, \omega$-Dicarboxylates: 1D to Polycatenated 3D Species. Inorg. Chem. 2019, 58, 567-580. 
33. Thuéry, P.; Atoini, Y.; Harrowfield, J. Chiral Discrete and Polymeric Uranyl Ion Complexes with $(1 R, 3 S)-(+)$-Camphorate Ligands: Counterion-Dependent Formation of a Hexanuclear Cage. Inorg. Chem. 2019, 58, 870-880.

34. Schöne, S.; Radoske, T.; März, J.; Stumpf, T.; Ikeda-Ohno, A. Synthesis and Characterization of Heterometallic Iron-Uranium Complexes with a Bidentate N-Donor Ligand (2,2'Bipyridine or 1,10-Phenanthroline). Inorg. Chem. 2018, 57, 13318-13329.

35. Groom, C. R.; Bruno, I. J.; Lightfoot, M. P.; Ward, S. C. The Cambridge Structural Database. Acta Crystallogr., Sect. B 2016, 72, 171-179.

36. Puttreddy, R.; Hutchison, J. A.; Gorodetski, Y.; Harrowfield, J.; Rissanen, K. Enantiomer Separation of Tris(2,2'-bipyridine)ruthenium(II): Interaction of a $D_{3}$-Symmetric Cation with a $C_{2}$-Symmetric Anion. Cryst. Growth Des. 2015, 15, 1559-1563.

37. Hooft, R. W. W. COLLECT, Nonius BV: Delft, The Netherlands, 1998.

38. Otwinowski, Z.; Minor, W. Processing of X-Ray Diffraction Data Collected in Oscillation Mode. Methods Enzymol. 1997, 276, 307-326.

39. Sheldrick, G. M. SHELXT - Integrated Space-Group and Crystal-Structure Determination. Acta Crystallogr., Sect. A 2015, 71, 3-8.

40. Sheldrick, G. M. Crystal Structure Refinement with SHELXL. Acta Crystallogr., Sect. C 2015, $71,3-8$.

41. Hübschle, C. B.; Sheldrick, G. M.; Dittrich, B. ShelXle: a Qt Graphical User Interface for SHELXL. J. Appl. Crystallogr. 2011, 44, 1281-1284.

42. Farrugia, L. J. WinGX and ORTEP for Windows: an Update. J. Appl. Crystallogr. 2012, 45, $849-854$.

43. Momma, K.; Izumi, F. VESTA 3 for Three-Dimensional Visualization of Crystal, Volumetric and Morphology Data. J. Appl. Crystallogr. 2011, 44, 1272-1276. 
44. Blatov V. A. Nanocluster Analysis of Intermetallic Structures with the Program Package TOPOS. Struct. Chem. 2012, 23, 955-963.

45. Weng, Z.; Zhang, Z. H.; Olds, T.; Sterniczuk, M.; Burns, P. C. Copper(I) and Copper(II) Uranyl Heterometallic Hybrid Materials. Inorg. Chem. 2014, 53, 7993-7998.

46. Thuéry, P.; Harrowfield, J. Uranyl Ion Complexes with Long-Chain Aliphatic $\alpha \omega-$ Dicarboxylates and 3d-Block Metal Counterions. Inorg. Chem. 2016, 55, 2133-2145.

47. Irving, H.; Mellor, D. H. The Stability of Metal Complexes of 1,10-Phenanthroline and its Analogues. Part I. 1,10-Phenanthroline and 2,2'-Bipyridyl. J. Chem. Soc. 1962, 5222-5237.

48. Spek, A. L. Structure Validation in Chemical Crystallography. Acta Crystallogr., Sect. D 2009, $65,148-155$.

49. Taylor, R.; Kennard, O. Crystallographic Evidence for the Existence of C-H $\cdots \mathrm{O}, \mathrm{C}-\mathrm{H} \cdots \mathrm{N}$, and C-H‥Cl Hydrogen Bonds. J. Am. Chem. Soc. 1982, 104, 5063-5070.

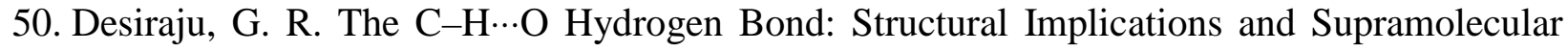
Design. Acc. Chem. Res. 1996, 29, 441-449.

51. Spackman, M. A.; Jayatilaka, D. Hirshfeld Surface Analysis. CrystEngComm 2009, 11, 1932.

52. Wolff, S. K.; Grimwood, D. J.; McKinnon, J. J.; Turner, M. J.; Jayatilaka, D.; Spackman, M. A. CrystalExplorer; University of Western Australia: Crawley, Australia, 2012.

53. Raithby, P. R.; Shields, G. P.; Allen, F. H.; Motherwell, W. D. S. Structure Correlation Study of Four-Coordinate Copper(I) and (II) Complexes. Acta Crystallogr., Sect. B 2000, 56, 444454.

54. Liu, C.; Chen, F. Y.; Tian, H. R.; Ai, J.; Yang, W.; Pan, Q. J.; Sun, Z. M. Interpenetrated Uranyl-Organic Frameworks with bor and pts Topology: Structure, Spectroscopy, and Computation. Inorg. Chem. 2017, 56, 14147-14156. 
55. Wang, S.; Mei, L.; Yu, J. P.; Hu, K. Q.; Liu, Z. R.; Chai, Z. F.; Shi, W. Q. Large-Pore Layered Networks, Polycatenated Frameworks, and Three-Dimensional Frameworks of Uranyl Tri(biphenyl)amine/Tri(phenyl)amine Tricarboxylate: Solvent-/Ligand-Dependent Dual Regulation. Cryst. Growth Des. 2018, 18, 4347-4356.

56. Zhang, X. L.; Hu, K. Q.; Mei, L.; Zhao, Y. B.; Wang, Y. T.; Chai, Z. F.; Shi, W. Q. Semirigid Tripodal Ligand Based Uranyl Coordination Polymer Isomers Featuring 2D Honeycomb Nets. Inorg. Chem. 2018, 57, 4492-4501.

57. Go, Y. B.; Wang, X.; Jacobson A. J. (6,3)-Honeycomb Structures of Uranium(VI) Benzenedicarboxylate Derivatives: The Use of Noncovalent Interactions to Prevent Interpenetration. Inorg. Chem. 2007, 46, 6594-6600.

58. Alexandrov, E. V.; Blatov, V. A.; Proserpio, D. M. How 2-Periodic Coordination Networks are Interweaved: Entanglement Isomerism and Polymorphism. CrystEngComm 2017, 19, 1993-2006.

59. Brachmann, A.; Geipel, G.; Bernhard, G.; Nitsche, H. Study of Uranyl(VI) Malonate Complexation by Time Resolved Laser-Induced Fluorescence Spectroscopy (TRLFS). Radiochim. Acta 2002, 90, 147-153.

60. Xie, J.; Wang, Y.; Liu, W.; Lin, X.; Chen, L.; Zou, Y.; Diwu, J.; Chai, Z.; Albrecht-Schmitt, T. E.; Liu, G.; Wang, S. Highly Sensitive Detection of Ionizing Radiations by a Photoluminescent Uranyl Organic Framework. Angew. Chem. Int. Ed. 2017, 56, 7500-7504.

61. Wang, Y.; Yin, X.; Liu, W.; Xie, J.; Chen, J.; Silver, M. A.; Sheng, D.; Chen, L.; Diwu, J.; Liu, N.; Chai, Z.; Albrecht-Schmitt, T. E.; Wang, S. Emergence of Uranium as a Distinct Metal Center for Building Intrinsic X-ray Scintillators. Angew. Chem. Int. Ed. 2018, 57, 7883-7887. 
For Table of Contents Use Only

\section{Tubelike Uranyl-Phenylenediacetate Assemblies from Screening of Ligand Isomers and Structure-Directing Counterions}

Pierre Thuéry, Youssef Atoini and Jack Harrowfield

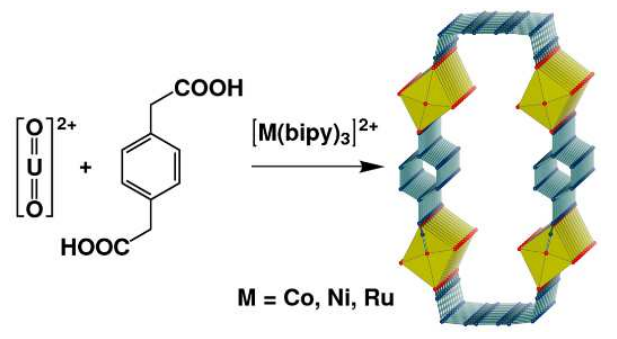

Ten uranyl ion complexes with 1,2-1,3-, or 1,4-phenylenediacetate ligands have been obtained in the presence of transition metal cations and bipy or phen molecules. Screening of the different diacetate/counterion associations enabled isolation of diverse one- and two-dimensional coordination polymers, the most original being tubelike assemblies including the counterions in their cavity. 